\title{
Paleomagnetism in Mesozoic rocks of the Northern Andes and its Implications in Mesozoic Tectonics of Northwestern South America
}

\author{
Germán Bayona ${ }^{1}$, Augusto Rapalini ${ }^{2}$, and Vincenzo Costanzo-Alvarez ${ }^{3}$ \\ ${ }^{1}$ Corporación Geológica Ares, Calle 57 No. 23-09 of 202, Bogotá, Colombia \\ ${ }^{2}$ Instituto de Geofísica Daniel Valencio (INGEODAV), Departamento de Ciencias Geológicas, FCE y N, Universidad de Buenos Aires, \\ Pabellón 2, Ciudad Universitaria, 1428, Buenos Aires, Argentina \\ ${ }^{3}$ Departamento de Ciencias de la Tierra, Universidad Simón Bolívar, Apartado 89000, Caracas 1081-A, Venezuela
}

(Received December 13, 2005; Revised April 11, 2006; Accepted April 28, 2006; Online published November 8, 2006)

\begin{abstract}
New paleomagnetic data isolated in Upper Triassic to Aptian rocks exposed in the Colombian Andes and west of the Guyana craton, in conjunction with paleomagnetic data from the Andes of Venezuela and the South American craton, permit the interpretation of along-margin northward translations of Andean Colombian terranes during the Early-Middle Jurassic. Field tests and comparison with reference paleopoles for South America indicate that characteristic components uncovered in red-siliciclastic and igneous rocks are primary, or neardepositional, and they are carried dominantly by hematite, magnetite and Ti-magnetite. Difference in declination values of characteristic components isolated in fault-bounded blocks document counter-clockwise rotations previous to syn-extensional deposition. The Jurassic tectonic scheme proposed here for the northwestern corner of South America shows an Early Jurassic, linear subduction-related magmatic arc evolving to Late Jurassic riftrelated setting associated to the opening of the Proto-Caribbean Ocean and westward retreat of the subduction zone. A similar tectonic evolution for the Jurassic has been proposed for southwestern USA and the Nazas arc in Mexico.
\end{abstract}

Key words: Paleomagnetism, Jurassic, Northern Andes, Tectonics.

\section{Introduction}

Triassic and Jurassic units exposed in the Andes of Ecuador, Colombia and Venezuela (Fig. 1) encompass a complex association of limestone, red siliciclastic, volcaniclastic and plutonic rocks (Mojica et al., 1996). Two tectonic settings have been proposed for these Mesozoic rocks: (1) an early Mesozoic continental magmatic arc and backarc basin (e.g., Pindell and Tabbutt, 1995), that in the north developed between the southwestern United States and Guatemala (Nazas arc; Bartolini, et al., 2003 and references there in), and (2) an extensional tectonic regime associated with the break up of Pangea and opening of the proto-Caribbean sea and Gulf of Mexico (e.g., Jaillard et al., 1990; Cediel et al., 2003). The controversy about which tectonic scenario dominates is in part due to the lack of reliable geochronological, biostratigraphic, and geochemical analyses. In addition, these tectonic analyses for the early Mesozoic have not considered any significant paleolatitudinal translation of terranes west of the Guyana craton that may be determined by paleomagnetism.

Previous paleomagnetic results from Middle Jurassic and younger rocks exposed in the Mérida Andes (Castillo et al., 1991) and Santa Marta massif (MacDonald and Opdyke, 1984) in the northern Andes indicate no paleolatitudinal translations of allochthonous terranes since the Mid-

Copyright (c) The Society of Geomagnetism and Earth, Planetary and Space Sciences (SGEPSS); The Seismological Society of Japan; The Volcanological Society of Japan; The Geodetic Society of Japan; The Japanese Society for Planetary Sciences; TERRAPUB. dle Jurassic (Fig. 1A). Based on paleomagnetic studies, Gose et al. (2003) document clockwise vertical-axis rotations of fault-bounded blocks in the Perijá Range, but more complex vertical-axis rotations are inferred from the Santander massif (Hargraves et al., 1984), Upper Magdalena Valley (Scott, 1978) and Guajira (MacDonald and Opdyke, 1972). Here, we present the results of a paleomagnetic and magnetic mineralogy study carried out in Upper Triassic to Aptian rocks cropping out in the Eastern Cordillera and Upper Magdalena Valley (Fig. 1A), between the Borde Llanero and Romeral fault systems. Our results are compared with previous data from the northern Andes and cratonic South America in order to evaluate potential paleolatitudinal translation of terranes and vertical-axis rotations of fault-bounded blocks during the Mesozoic.

\section{Regional Setting}

In Colombia, the Andes branches into three major mountain ranges, the Western, Central and Eastern Cordilleras, which are separated by the Cauca and Magdalena valleys. The Romeral fault system (Fig. 1A) is considered a paleosuture that places terranes of oceanic affinity against terranes cored with continental crust (e.g., Etayo-Serna et al., 1983; Cediel et al., 2003). Farther north, and east of the Bucaramanga fault, four mountain ranges constitute the northern continuity of the Andes. Paleomagnetic and geochemical studies in Cretaceous and Tertiary rocks exposed in terranes westward of the Romeral paleosuture have documented the oceanic affinity and allochthonous character of such blocks (Estrada, 1995; Kerr and Tarney, 2005). 
A.

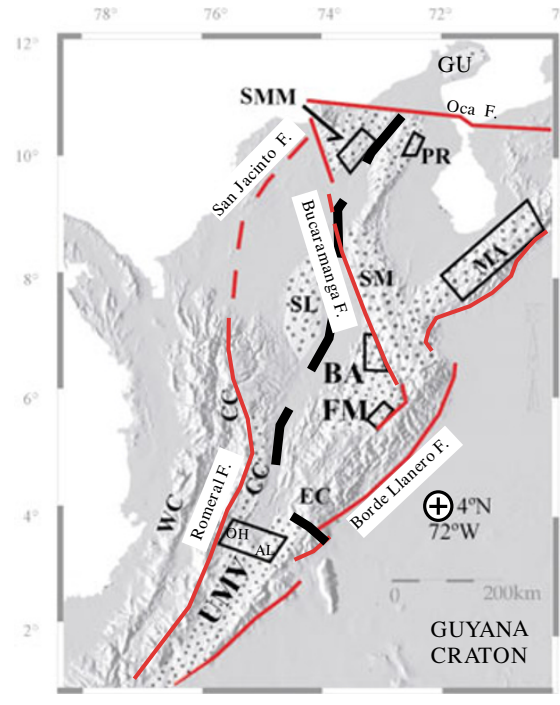

Study areas:

BA - Bucaramanga

FM - Floresta massif

UMV - Upper Magdalena Valley:

$\mathrm{OH}=$ Olaya Herrera

$\mathrm{AL}=$ Alpujarra

Mountain ranges:

CC - Central Cordillera

EC - Eastern Cordillera

WC - Western Cordillera

PR - Perijá range

GU - Guajira

MA - Mérida Andes

SL - San Lucas range

SM - Santander massif

SMM - Santa Marta massif

Mountain ranges with exposed TriassicJurassic rocks

Boundary between western and eastern compartments (after Sarmiento-Rojas, 2001)

B.

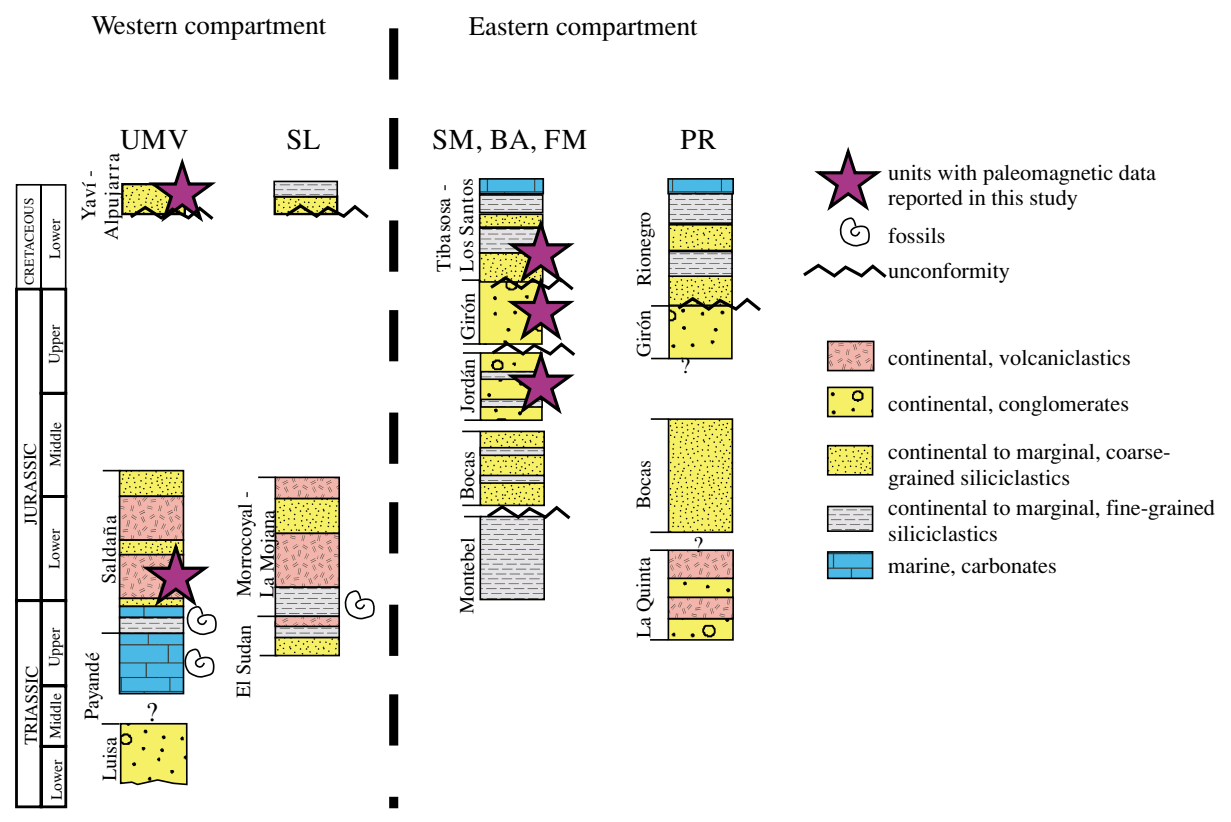

Fig. 1. (A) Location of areas with paleomagnetic analysis in the northern Andes, and present structural position of mountain ranges with exposed Triassic-Jurassic rocks between the Borde Llanero and Romeral-San Jacinto-Oca fault systems. Jurassic strata exposed north of the Oca Fault (GU) are not discussed in this paper. (B) Schematic stratigraphic position and major lithologies of Triassic to Lower Cretaceous beds exposed in the eastern and western compartments. Units discussed in the text are in bold.

The pre-Cretaceous history of terrane accretion between the Guyana craton and the Romeral paleosuture is still poorly understood due in part to the structural complexity and poly-deformed character of those terranes. Detailed geochronological and geochemical analyses in granulitecored basement uplifts of Grenvillian age in the northern Andes reveal an affinity with terranes of Mexico and the Central Andes (Restrepo-Pace et al., 1997; Cordani et al., 2005). Fragmentation of these terranes took place during the early Paleozoic (Cordani et al., 2005), but collisions between Grenvillian-age basement blocks and Gondwana during the aggregation of Pangea remains uncertain (SilurianEarly Devonian, Forero, 1990; Restrepo-Pace, 1992); perhaps, yet unknown later translations to its present latitudinal position were important. An alternative hypothesis considers that geotectonic units west of the Guyana craton are in situ, and constitute the westward growth of the plate margin (Mojica et al., 1996). When and how these terranes formed, collided and arrived to its present geographic position remains unclear and deserves significant further research.

Previous tectonic reconstructions for Mesozoic deformational events that affected the area between the Romeral paleosuture and the craton have not considered along-platemargin displacements or rotations of terranes. Recent revisions of Mesozoic tectonics in northern South America consider accumulation of Triassic and Jurassic sedimentary rocks in rift-related extensional basins (e.g., Mojica et al., 1996; Cediel et al., 2003). Major, trace and rare earth elements analyses yield subduction-related magmatism in Upper Triassic-Jurassic igneous, volcanic and volcaniclastic rocks in the Central Cordillera (Aspden et al., 1987; Altenberger and Concha-Perdomo, 2005), Upper Magdalena 
Valley (Bayona et al., 1994; Castañeda, 2002; Cajas, 2003; Vasquez et al., 2006), San Lucas Range (Vasquez et al., 2006), Santander massif (Dorr et al., 1995) and Perijá Range (Maze, 1984). Large granite-to-diorite intrusions in the Santander massif (Ward et al., 1973) might have occurred in a back-arc setting and induced a local metamorphic event as suggested by Restrepo-Pace (1995) based on ${ }^{40} \mathrm{Ar} /{ }^{39} \mathrm{Ar}$ geochronology, petrology and field observations. In short, geochemical data support the influence of continental-margin magmatism, whereas sedimentary successions indicate deposition in extensional settings.

The present Andean distribution of terranes with Triassic-Jurassic volcanic and plutonic rocks makes difficult to explain two or three parallel magmatic-arcs related to a single subduction margin. One belt with Triassic-Jurassic rocks in southern Colombia (UMV and eastern flank of the $\mathrm{CC}$ ) bifurcates into two belts in central Colombia (SL to the West and FM-BA-SM to the East), and then into three belts (from East to West are: MA, PR, SMM) in northern Colombia and Venezuela (Fig. 1A). Sarmiento-Rojas (2001) suggested that Jurassic sedimentation occurred in two separate basin compartments, based on lithofacies and thickness similarities and related to their geographic position. The western compartment (eastern flank of the CC, UMV, SL, SMM in Fig. 1A) includes Upper Triassic-Lower Jurassic shallow-marine strata covered with a 1-km-thick volcanic-related succession, and Aptian-Albian rocks unconformably overlie this succession (Fig. 1B). Large intermediate plutonic bodies define the western limit of the western compartment. In contrast, the eastern compartment (EC, FM, SM, PR and MA in Fig. 1A) consists mostly of Jurassic continental sedimentary rocks, interbedded with volcaniclastic rocks in PR and MA, and they are overlain by a thick Lower Cretaceous succession. In the Santander massif (SM), granite-to-diorite intrusive rocks cut this succession (Ward et al., 1973).

\section{Study Areas and Sampling Strategy}

The areas selected for this study are both in the eastern (FM and BA) and western (UMV) compartments defined by Sarmiento-Rojas (2001). The stratigraphic position of selected units and regional geologic maps showing the structural setting of selected areas are shown in Figs. 1B and 2, respectively. In each selected area, sites were distributed in at least two structural domains in order to perform the tilt test. Sites in unconformable upper or lower units were collected in order to compare characteristic directions between units (i.e., unconformity test). Samples in dykes and conglomerate clasts were taken in order to establish the relative age of magnetization.

A total of 389 specimens distributed in 41 sites were collected for this study. In Bucaramanga (BA) red-siliciclastic beds with minor volcanic interbeds of the Jordán (LowerMiddle Jurassic), Girón and Los Santos Fms (Upper Jurassic-Berriasian) were collected in two structural domains, named the northern and southern blocks (Fig. 2A). The Jordán Fm underlies the Girón Fm in an unconformable contact, which has $10-15^{\circ}$ angularity in some areas (Ward et al., 1973). The contact between the Girón and Los Santos Fms is also considered as an unconformity. The eastern side of the northern block is highly deformed by strike-slip faults associated to the Bucaramanga fault, whereas the western side has broad folds and then the beds dip uniformly westward. In contrast, the southern block is in a very stable and sub-horizontal region. Stratigraphic columns for each site and a complete list of analyzed sites are in Ayala-Calvo et al. (2005).

In the Floresta massif (FM), sites were distributed in the western and eastern flanks of an antiform cored by the massif, and in the southern end of the massif (Fig. 2B). Red siliciclastic beds of the Upper Jurassic Girón Fm and limestone beds of the Valanginian Tibasosa Fm were sampled in those structural domains. The Girón Fm unconformably rests on several Paleozoic units, and siliciclastic strata of the lower Tibasosa Fm cover the red siliciclastic succession of the Girón Fm in a paraconformity contact. Four sites in fine-grained strata and 2 sites in conglomerate beds were located in a 130-m thick stratigraphic column of the Girón Fm in order to perform the conglomerate tests and check by reversal of paleomagnetic directions. Stratigraphic columns and components of magnetization no reported here because of its high dispersion or anomalous directions are reported in Ayala-Calvo et al. (2005).

Two areas were selected in the northern Upper Magdalena Valley (UMV, Fig. 2C), where the Aptian Yaví Fm rests in an angular unconformity upon Upper TriassicLower Jurassic Saldaña Fm. In Olaya Herrera area $(\mathrm{OH})$, located close the Jurassic magmatic belt exposed in the Central Cordillera, samples were collected from lavas and red-volcaniclastic beds of the Saldaña Fm at the southeastern and northwestern flank of an anticline structure along the Chipalo river, as well as in the Macule river (Fig. 2D). Note that Yaví strata are only recorded in the latter block. Even though samples of Cretaceous units were collected at these three localities, a characteristic component was not isolated (Bayona et al., 2005). In Alpujarra (AL), an area located near the western margin of the Eastern Cordillera of Colombia, sites of the Yaví Fm were collected in two thrust sheets, named the eastern and western thrust sheets. The sampled lithologies in the Yaví Fm were tuffs and red mudstones to very fine-grained sandstones. Sites in the Saldaña Fm were also collected; however, high-temperature magnetization components uncovered in these rocks yield a very disperse orientation. Details of stratigraphic columns and statistics of Saldaña and Yaví sites are in Bayona et al. (2005).

\section{Methods}

Thermal and AF progressive demagnetization analysis were carried out at the Paleomagnetic laboratories of Ingeominas (Colombia) and the Universidad de Buenos Aires (Argentina). Components of magnetization were calculated by means of Principal Component Analysis (Kirschvink, 1980) interpreted with the aid of orthogonal demagnetization diagrams (Zijderveld, 1967). Mean magnetization directions were calculated using Fisher's statistics (Fisher, 1953). Local incremental tilt tests (McFadden and Reid, 1982) were used to determine the timing of magnetization with respect to Cenozoic deformation. The significance of the tilt test followed the criteria of McElhinny (1964) 
A. BUCARAMANAGA (BA-11 sitios) (modified from Ayala et al., 2005)
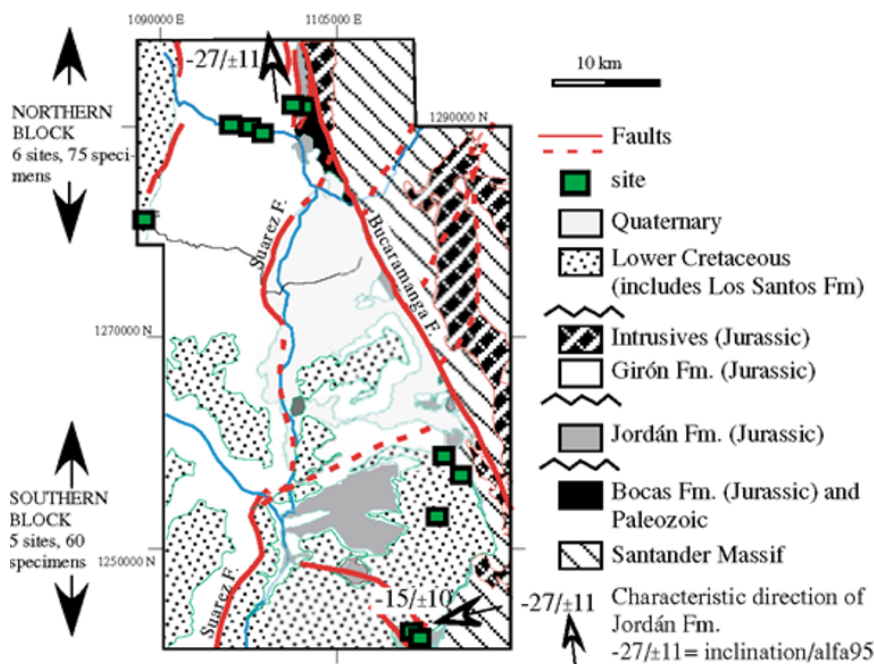

B. FLORESTA MASSIF (FM-11 sites) (modified from Ayala et al., 2005)

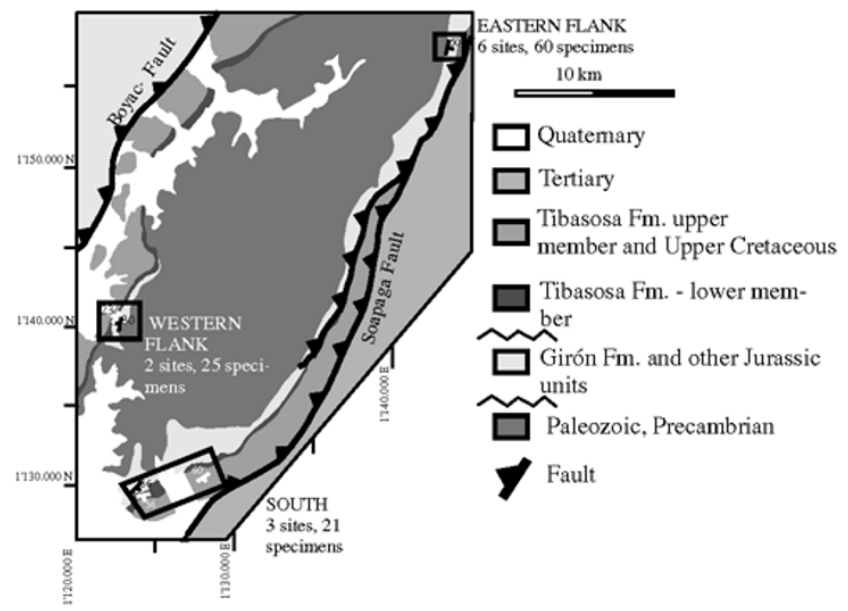

D. OLAYA HERRERA (OH-12 sites)

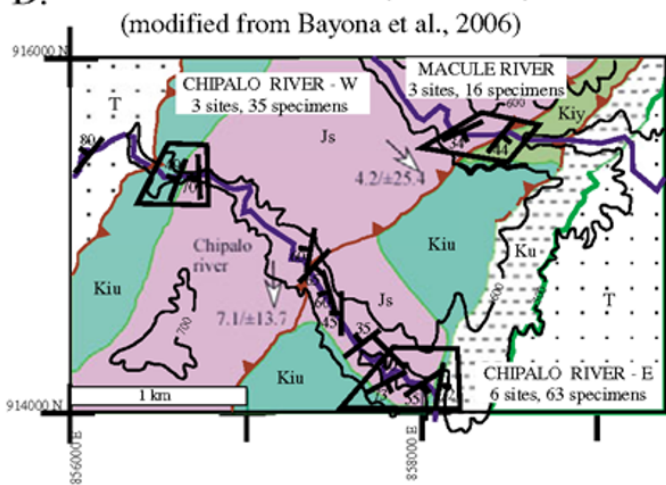

E.

ALPUJARRA (AL-7 sites)

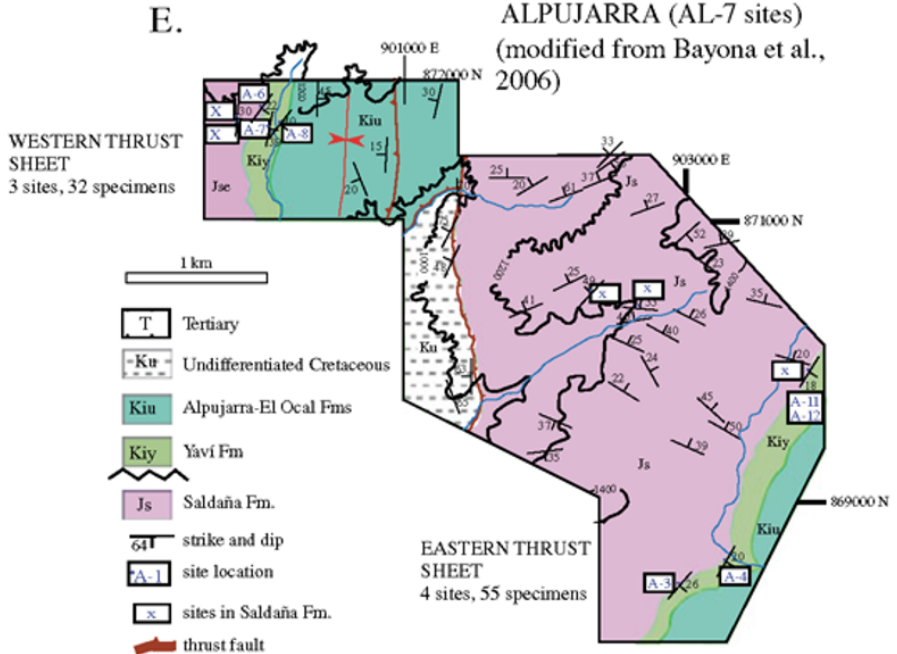

Fig. 2. Regional geologic setting of the (A) Bucaramanga area (BA) and (B) Floresta massif (FM) showing location of structural domains and paleomagnetic sites. (C) Geologic map of the Upper Magdalena Valley (UMV) showing exposures of intrusives and volcaniclastic beds and the location of the two selected areas. (D) and (E) Detailed geologic maps of the Olaya Herrera (OH) and Alpujarra (AL) areas showing location of structural domains and paleomagnetic sites. Arrows in A, C and D show the mean declination of characteristic directions for each structural domain.

because of the limited number of sites per structural domain. Classification of the reversal test follows McFadden and McElhnny (1990) criteria. The mean VGPs (virtual geomagnetic poles) determined from the characteristic components of each formation at each locality were later com- pared with the reference poles for the South American cratonic areas in order to infer tectonic implications. Thermomagnetic curves and thermal demagnetizations of composite orthogonal IRMs (Lowrie, 1990) have been conducted at the Universidad Simón Bolivar (Venezuela) in 16 rep- 
A Jordán Fm (red siltstone)

BA (Southern block)

(site M6, specimen m58)

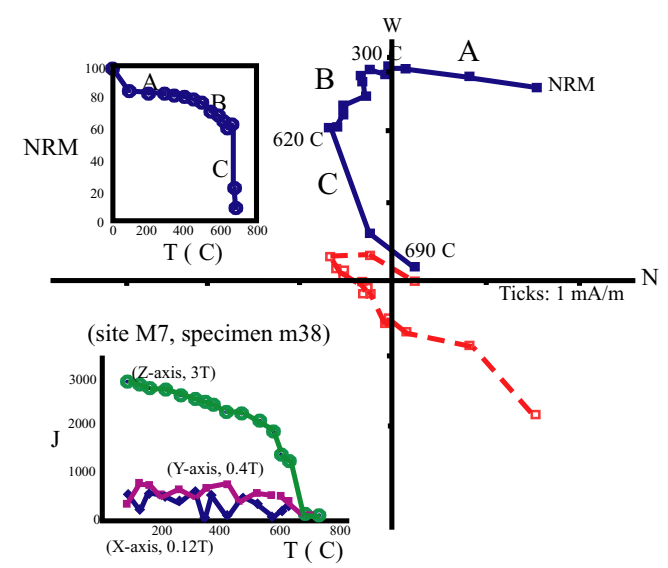

C Saldaña Fm (dyke)

Olaya Herrera-UMV

(site $\mathrm{O} 5$, specimen o83b)

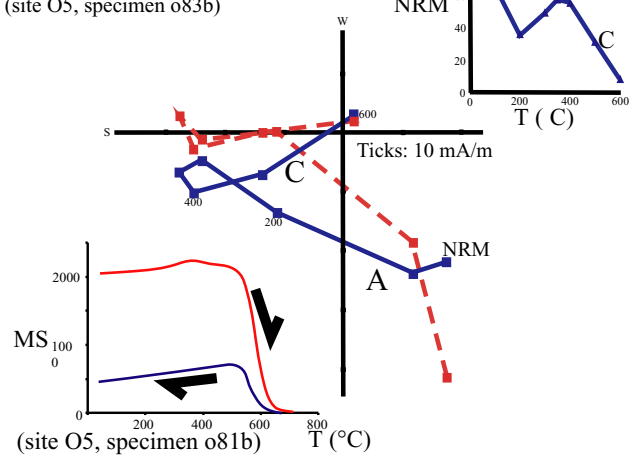

B

Girón Fm (red sandy siltstone)

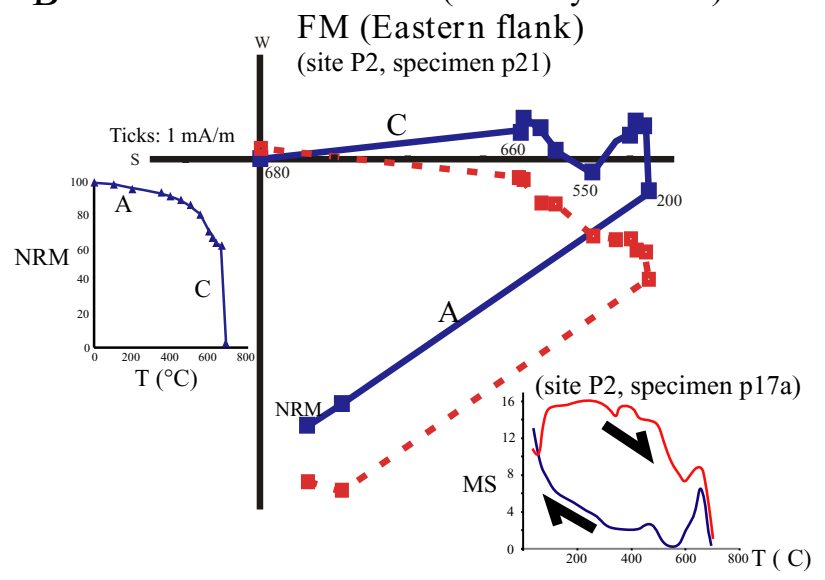

D Yaví Fm (tuff) Alpujarra-UMV (site A6, specimen a61)

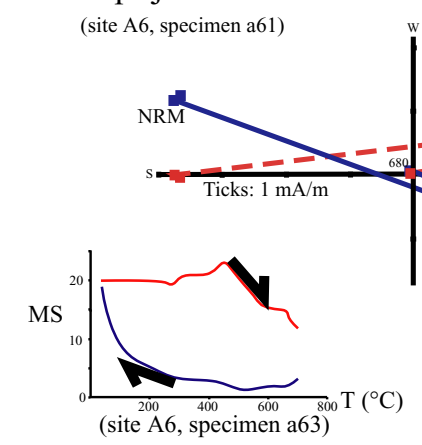

E Girón Fm. (red sandy siltstone) BA (Northern block) (site M2, specimen m19)

F Saldaña Fm. (tuff)

Olaya Herrera-UMV

(site O14, specimen o66)

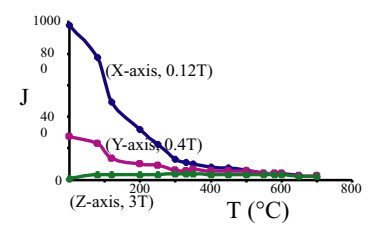

Fig. 3. Orthogonal diagrams of demagnetization and rock magnetic properties of representative samples. Full (open) symbols in Zijderveld plots represent projections onto the horizontal (vertical) plane.

resentative samples. In the Lowrie experiments, the IRMs were induced sequentially along the $Z(3 \mathrm{~T}), Y(0.4 \mathrm{~T})$ and $X$ $(0.12 \mathrm{~T})$ axis of the cylindrical specimens. Thermomagnetic curves were obtained using a Bartington MS2 with a MS2W probe that allows continuous susceptibility and temperature readings of a sample heated, up to $700^{\circ} \mathrm{C}$.

\section{Paleomagnetic and Rock Magnetic Results}

Demagnetization diagrams for the studied Mesozoic strata show univectorial to multivectorial paths (Fig. 3), the latter suggesting at least two events of magnetization. Both low-temperature/coercivity magnetic components and moderate to high-temperature/coercivity characteristic magnetic components were isolated from Upper Triassic to Aptian rocks exposed in the three selected areas (Tables 1,2 and 3).
The former components carry directions parallel to the present Earth magnetic field and were uncovered in all the three areas and in all the sampled units. These directions are interpreted as recently acquired thermoviscous or chemical magnetizations. Directions and unblocking temperature/coercivity for the characteristic components for each area (Table 4) are discussed in the following paragraphs for each area.

In the Bucaramanga area (BA, Fig. 2A), mean-site directions of tilt-corrected characteristic components from the Jordán Fm (Lower-Middle Jurassic) and Girón-Los Santos Fms (Upper Jurassic-Berriasian) show negative and positive inclinations, respectively. Tilt-corrected characteristic directions isolated in basalts and red siltstones of the Jordán Fm show northward and westward declinations with mod- 


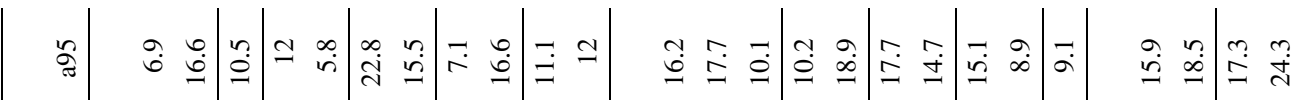

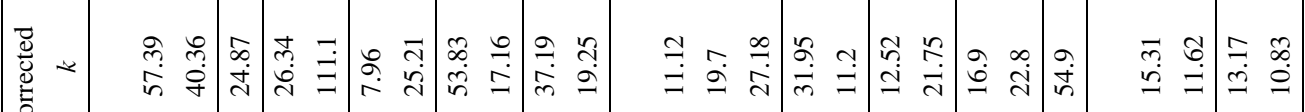

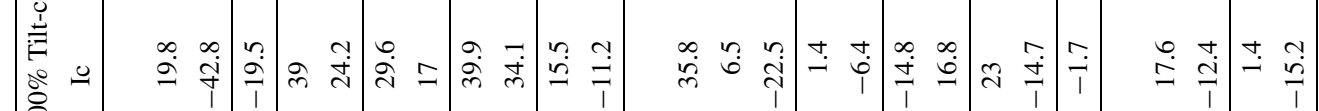

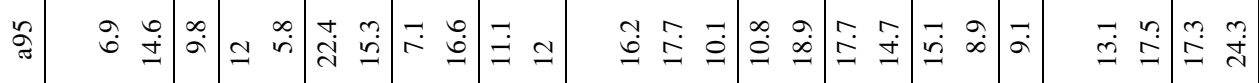

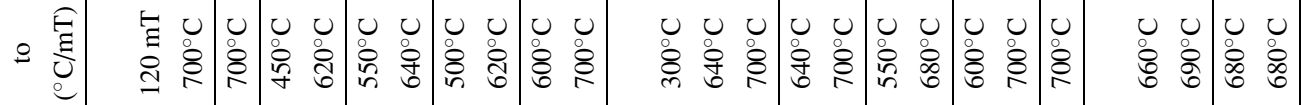

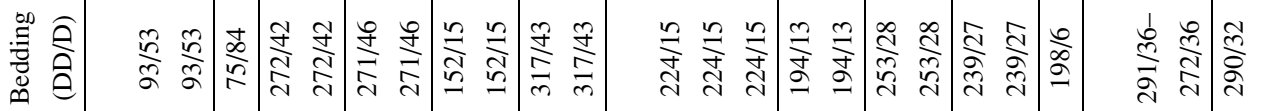




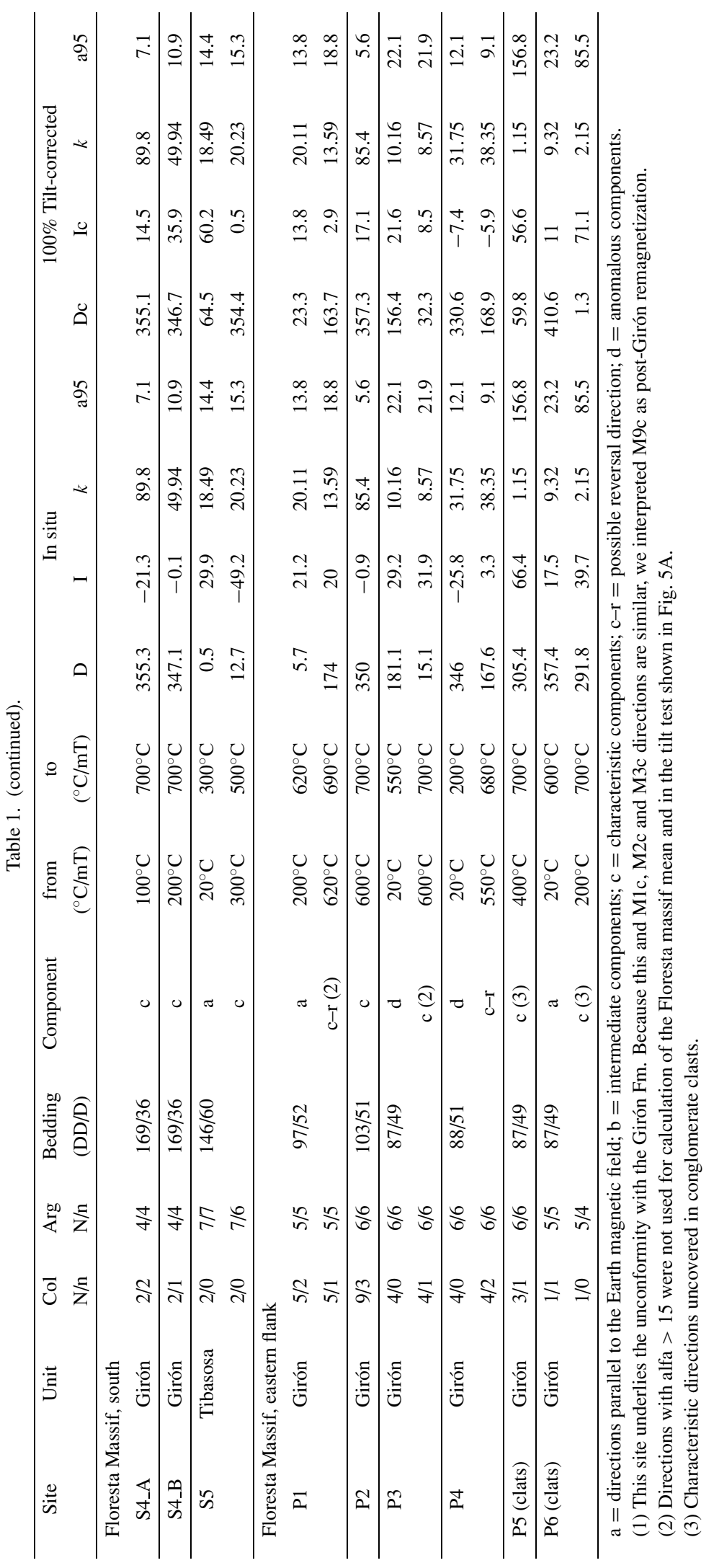




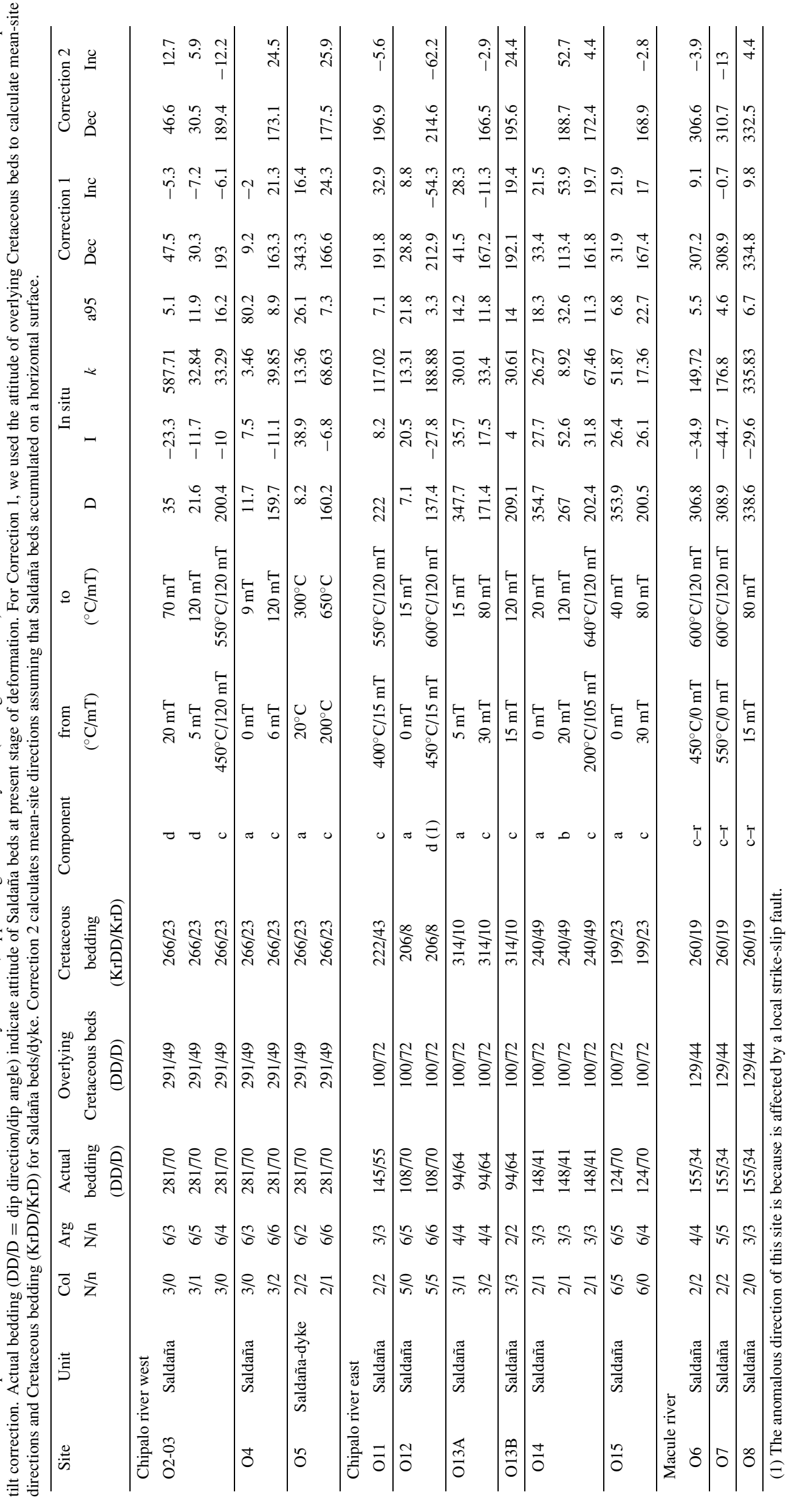




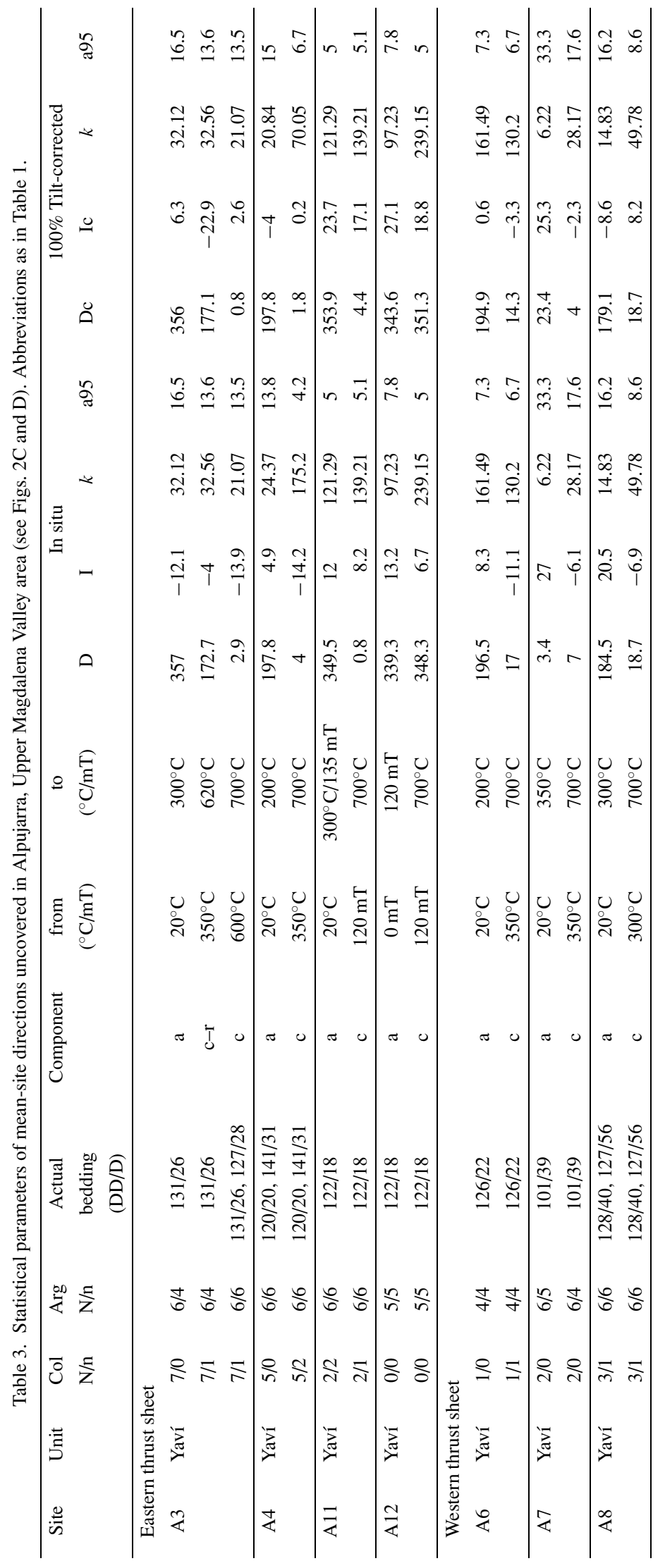




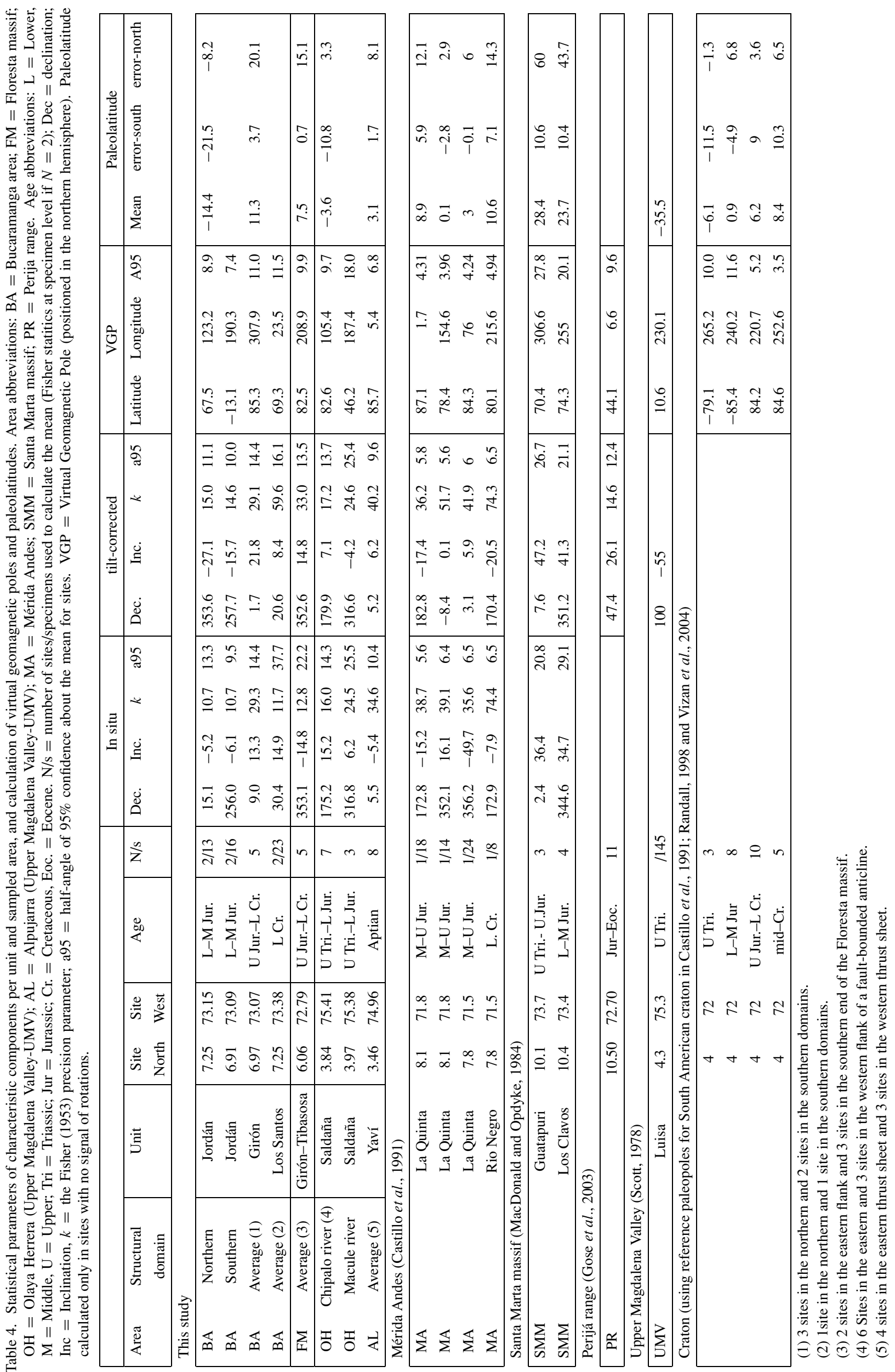


A. Upper Triassic - Middle Jurassic rocks

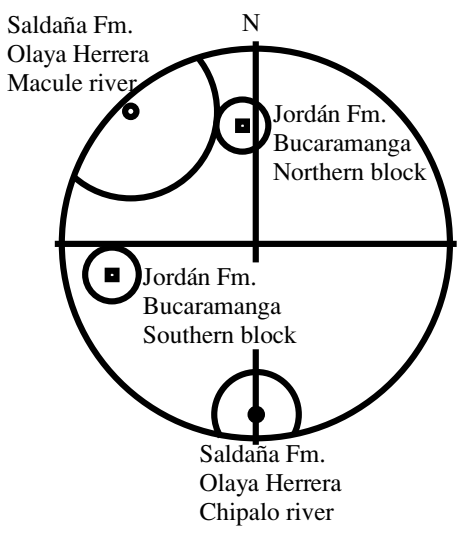

B. Upper Jurassic-Lower Cretaceous

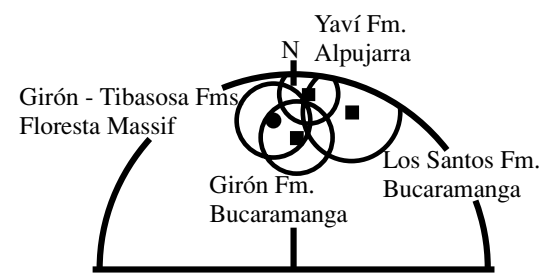

C. Other Mesozoic rocks

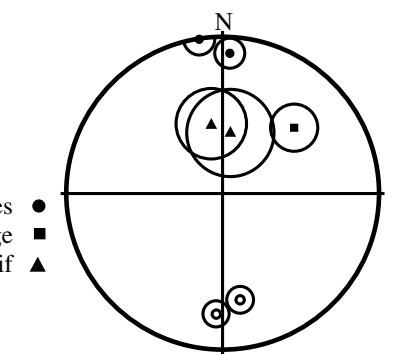

Fig. 4. A and B. Equal-area plots at different ages showing tilt-corrected directions of characteristic components per unit and sampled area. C. Tilt-corrected directions of characteristic components reported for other Triassic to Lower Cretaceous units in the northern Andes (see Table 4 for statistical parameters). Solid (open) symbols represent positive (negative) inclinations.

A. Tilt test (after McElhinny, 1964; McFadden and Reid, 1982)

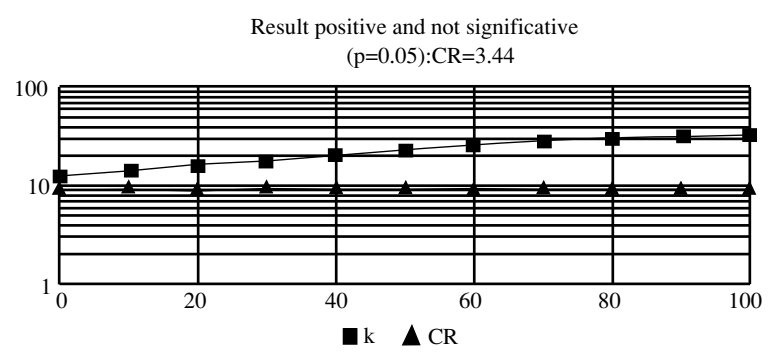

B. Normal and reverse tilt-corrected directions

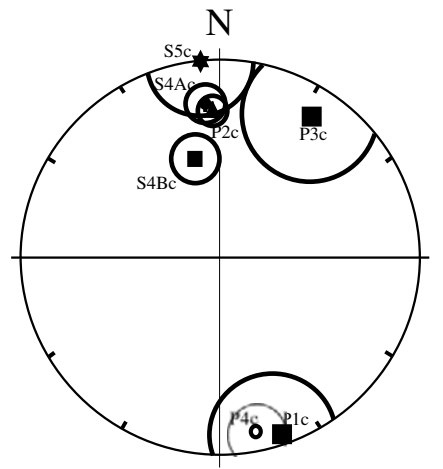

C. Conglomerate test tilt-corrected directions

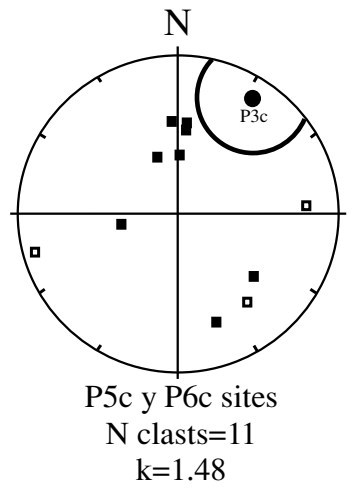

Fig. 5. Field tests for characteristic components of the Girón and Tibasosa Fms in the Floresta massif area. See text for discussion. A) The tilt test plots $k$ (squares, an estimate of the degree of clustering of inclination data on a sphere) and CR (triangles, a critical ratio above which $k$ values become significant at the 95\% confidence level) (McElhinny, 1964) versus percent of tilt-correction. B and C) For the reversal and conglomerate tests, sites P1 to P4 were sampled in a 130-m thick stratigraphic section, site P3 corresponds to a site in a siltstone bed interbedded with conglomerate beds of sites P5 and P6.

erate negative inclinations (Table 4, Fig. 4A). A significant $\mathrm{NRM}$ intensity drop over $600^{\circ} \mathrm{C}$ indicates that hematite is the dominant magnetic carrier of the characteristic components in these samples. Thermal demagnetization curves of the IRM induced along the $Z$-axis (3T) for a red siltstone sample of the Jordán Fm suggests that hematite is the chief magnetic phase (Fig. 3A). Characteristic directions isolated in fine-grained sandstones and mudstones of the Girón-Los Santos Fms have low to moderate positive inclinations with northward declinations (Table 4, Fig. 4B). Antipodal directions were isolated in both units (e.g., sites M10 and M16 in Table 1), and they had a classification " $C$ " in the reversal test. A thermomagnetic curve for a fine-grained sandstone from the Girón Fm shows a characteristic Timagnetite behaviour with a sharp reversible drop at about $580^{\circ} \mathrm{C}$ (Fig. 3E). The absence of a Hopkinson peak near the
Curie temperature of magnetite may be due to a distributed grain size spectrum for this sample (Wilson and Roberts, 1999).

In the Floresta massif (FM), the tilt-corrected mean direction of the characteristic magnetic component isolated in the Girón-Tibasosa Fms (Upper Jurassic-Valanginian) is similar to the direction isolated from rocks of the same age in Bucaramanga (Fig. 4B). After tilt correction, and integrating data from 5 sites of the Girón and Tibasosa Fms with alfa95 $<15^{\circ}$, clustering of directions increases (Table 4, Fig. 5A) showing a northward declination with low positive inclination. The presence of magnetite and hematite is revealed in the thermomagnetic heating curve (Fig. 3B) by the two susceptibility shoulders at about 580 and above $600^{\circ} \mathrm{C}$, respectively; unblocking temperatures of these components reveal the dominance of hematite over 


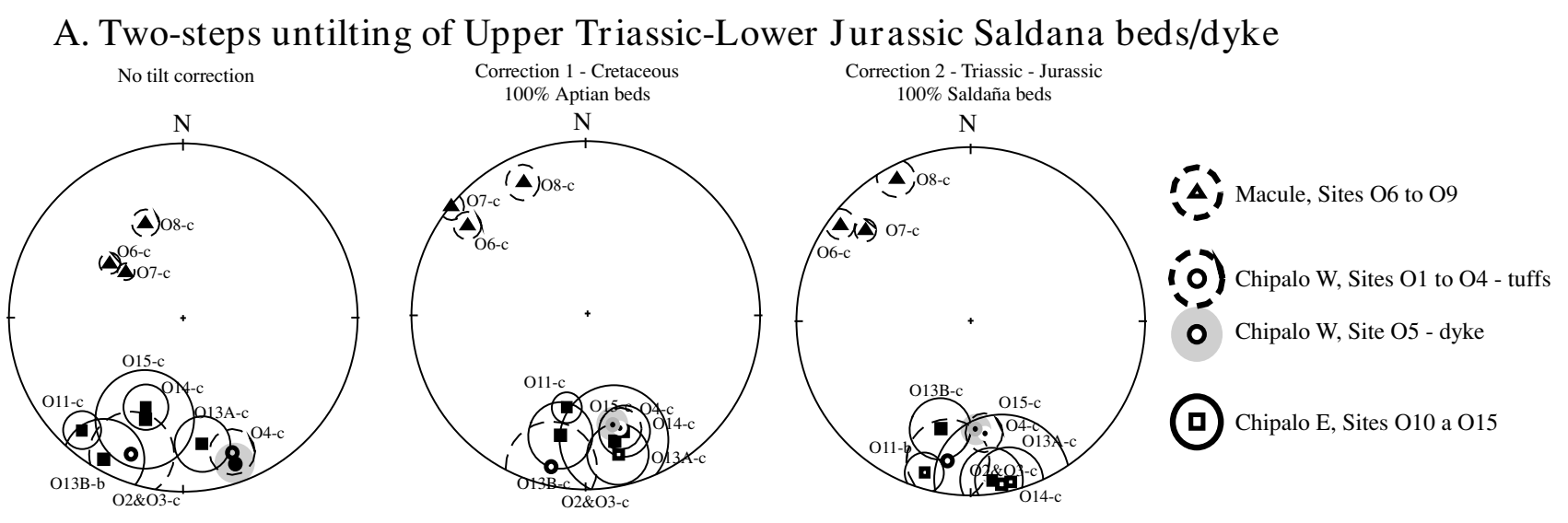

B. Untilting of Aptian Yavi beds
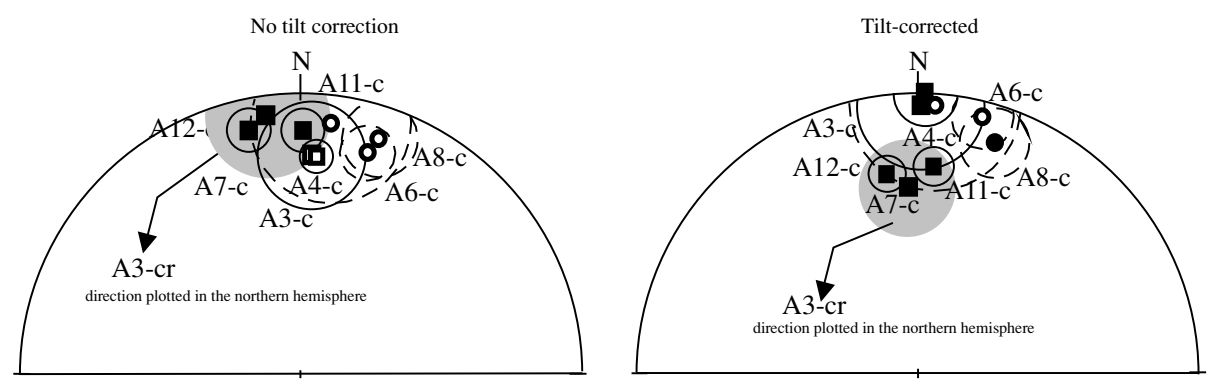

Fig. 6. Tilt-correction procedure of characteristic components in the Upper Magdalena Valley area. A) The best clustering of directions occurs after the two steps of tilt corrections for Saldana beds/dyke. B) Intermediate positive to nearly horizontal inclinations are obtained after tilt correction of characteristic directions uncovered in the Yaví Fm.

$600^{\circ} \mathrm{C}$ (Fig. 3B). Characteristic components isolated in limestones of the Tibasosa Fm have unblocking temperatures from 300 to $500^{\circ} \mathrm{C}$, suggesting the presence of $\mathrm{Fe}$ sulphides and/or titanomagnetite.

In the northern UMV, characteristic components of magnetization in the Upper Triassic-Lower Jurassic Saldaña Fm and the Aptian Yaví Fm were isolated in Olaya Herrera $(\mathrm{OH})$ and Alpujarra $(\mathrm{AL})$, respectively. In Olaya Herrera area $(\mathrm{OH})$, characteristic directions were isolated in lavas and tuffs as well as in dykes of the Saldaña Fm (Fig. 3C) exposed in the three structural domains (Fig. 2D). The best cluster of characteristic directions isolated along the Chipalo River occurs after two-steps tilt correction of Saldaña beds (Tables 2, 4 and Fig. 6A). The first correction considers untilting of overlying Cretaceous beds; the second correction is made by pre-Aptian tilt of Saldaña beds. Characteristic directions have southern declinations and shallow-positive inclinations, similar to the characteristic direction isolated in a dyke (Fig. 6A). After converting the characteristic direction of the Macule river to southern directions, the mean inclination values between Chipalo and Macule river blocks become similar but declinations show evidence for rotation (Table 4, Fig. 4A). Thermal demagnetizations of IRM fractions along the $X(0.12 \mathrm{~T})$ and $Y$ axis $(0.4 \mathrm{~T})$ for a tuff display a decaying trend over a wide range of unblocking temperatures that roughly extrapolates to complete demagnetization at around $350^{\circ} \mathrm{C}$ (Fig. $\left.3 \mathrm{~F}\right)$. We believe these observations are suggestive of the presence of either titanomagnetite, maghemite or an iron sulphide. A dyke reveals that magnetite appears to be the main magnetic phase in this sample (Fig. 3C).

In Alpujarra area (AL), characteristic directions isolated in volcanic-sedimentary rocks of the Yaví Fm (Fig. 3E) have both normal and reversed directions. A northward declination/positive inclination direction of the unit mean is obtained after tilt correction of beds (Table 4, Fig. 6B). Both magnetite and hematite record the characteristic component in the Yaví Fm as indicated by the two shoulders of the intensity decay curve during thermal demagnetization and the thermomagnetic heating curve, at 580 and above $600^{\circ} \mathrm{C}$, respectively (Fig. 3D).

\section{Timing of Magnetization for Characteristic Components}

Several of the field tests give a not significant statistics results or are rejected at $95 \%$ level of confidence; however, the visual comparison and association of field test allow us to suggest a relative age of magnetization.

A near-depositional magnetization of characteristic directions in Bucaramanga and Floresta massif areas is inferred by: (1) increasing cluster of the inclinations by untilting of strata in both areas (Table 4 and Fig. 5A); (2) normal and reversed directions isolated in the Girón Fm in both areas (Fig. 5B); (3) high dispersion of high-temperature components isolated in 11 clasts in conglomerate beds of the Girón Fm (Fig. 5C); (4) high stability of components carried by hematite in red siliciclastic rocks of the Jordan and Girón Fms; (5) different paleomagnetic directions in sites 

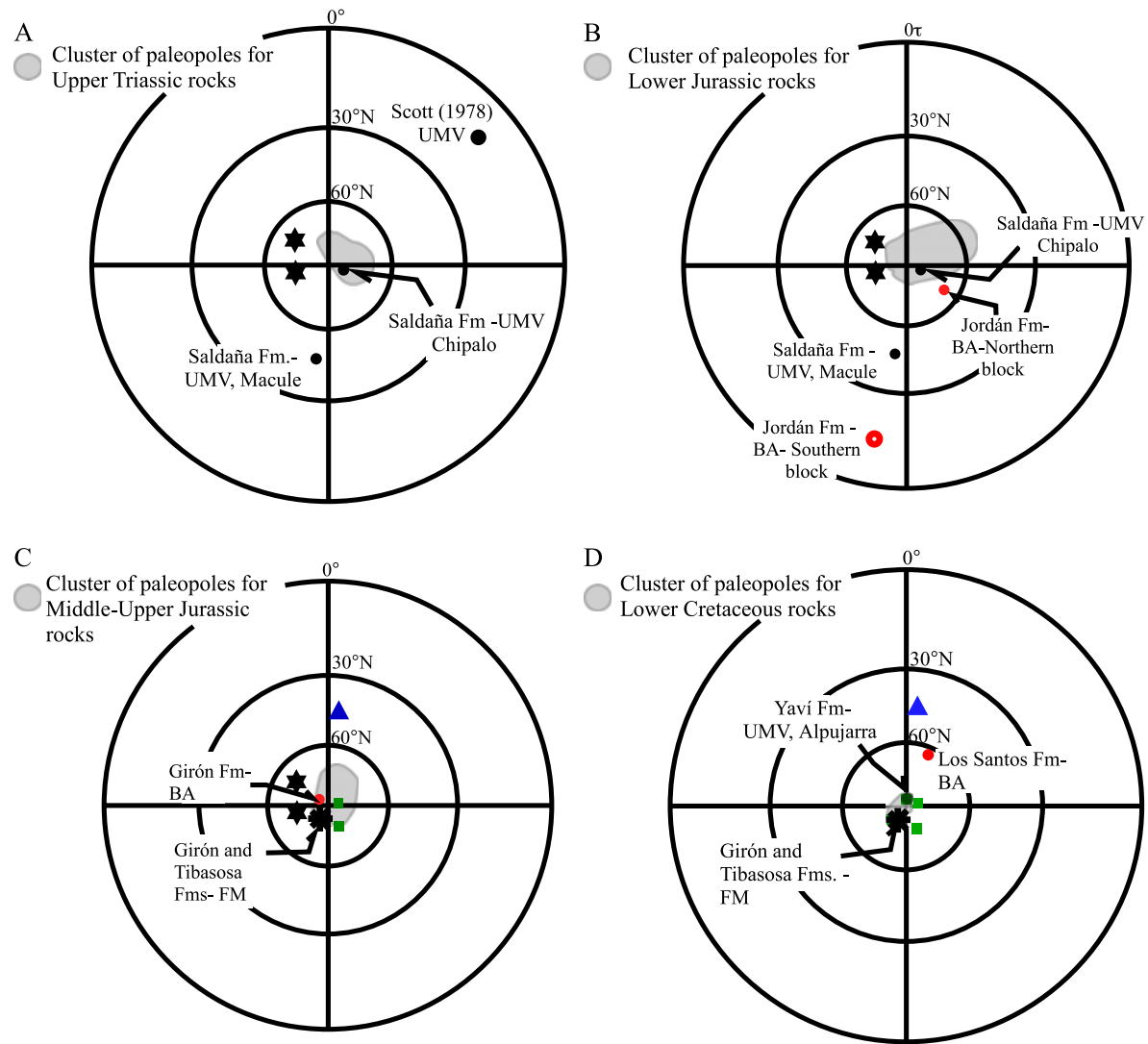

A Perij· Range (data from Jurassic to Eocene strata, Gose et al., 2003)

o- Bucaramanga area, BA (open circle plots in the southern hemisphere, Table 4)

"Wloresta massif, FM (Table 4)

- Upper Magdalena Valley, UMV (Table 4)

- Mérida Andes (data from La Quinta and Rio Negro Fms., Castillo et al., 1991)

* Santa Marta massif (data from Guatapurí and Los Clavos Fms; MacDonald and Opdyke,1984)

Fig. 7. Polar plots in the northern hemisphere for four intervals of time showing VGP's calculated for characteristic components isolated in this study and in other ranges of the northern Andes. For simplicity, circle of confidence for each VGP are not shown but values of A95 are in Table 4 . For each plot, the polygon encloses circles of confidence of VGP's calculated for the South American craton in Upper Jurassic to Lower Cretaceous rocks (data from: Castillo et al., 1991; Randall, 1998; McElhinny and McFadden, 2000; Iglesia Llanos et al., 2003; Somoza, 2002; Ernesto et al., 2002; Vizán et al., 2004).

of the Jordan/Girón Fms in Bucaramanga; and (6) different magnetic mineralogy assemblage in sites of the Tibasosa and Giron Fms in the Floresta massif.

The difference in characteristic directions between the Saldaña and Yaví units, the best clustering of directions of the Saldaña Fm after the two-step tilt corrections, and the similarity of directions between dykes and tuffs support a pre-Aptian (likely Jurassic) age of magnetization for rocks of the Saldaña Fm in $\mathrm{OH}$ and a mid-Cretaceous (AptianAlbian?) age for rocks of the Yaví Fm. Characteristic directions of Chipalo River Saldaña tuffs/dykes are nearly antiparallel to characteristic directions uncovered from the Jordán Fm (Lower-Middle Jurassic) in the northern block of BA (Fig. 4A), although the reversal test is rejected at 95\% level. The characteristic directions uncovered in Yaví beds are shallower than the directions from the Girón Fm and Lower Cretaceous units in BA and FM (Fig. 4B). Since there is not a characteristic component that could be associated with a specific magnetic carrier, we argue that most magnetic minerals in samples from the UMV were earlyacquired phases dating from incipient thermochemical process that could have affected these lithologies.

\section{Comparison of Characteristic Directions with Reference Paleopoloes for South America}

Even though the definition of Mesozoic paleopoles for the South American craton is still a matter of debate, comparison of VGPs calculated in this study with Late Triassic to Aptian-Albian South American paleopoles allows us to infer some tectonic implications (Fig. 7). First, characteristic directions with declinations close to the North-South line and VGP's latitudes higher than $65^{\circ}$ fall in the cloud of calculated paleopoles for the craton (Castillo et al., 1991; Randall, 1998; McElhinny and McFadden, 2000; Vizán et al., 2004 and references therein).

This exercise confirms that characteristic directions whose declinations significantly differ from the NorthSouth line can be interpreted as belonging to blocks with some degree of vertical-axis rotation. This is the case for westward declinations in rocks of the Jordán Fm (BA, southern block), southeastern declinations in rocks of the Saldaña Fm (UMV-Macule), directions reported by Scott (1978) in the UMV (Figs. 7A and B), as well as northeastern declinations reported for the Perijá range (Fig. 7C) (Gose et al., 2003). The VGP's calculated for characteristic 
directions reported for the Santa Marta massif by MacDonald and Opdyke (1984) also fall outside the cloud of paleopoles, suggesting an unresolved event of deformation for this mountain range. The paleopole calculated for the characteristic direction of the Los Santos Fm (Berriasian) in BA also falls outside from the cloud of circles of confidence from the paleopoles reported for Lower Cretaceous rocks in the South American craton (Fig. 7D).

\section{Evidence for Rotations}

Comparison of declinations of the Jordán and Saldaña Fms illustrate vertical-axis rotations between fault-bounded blocks. In BA, declinations of the Jordan Fm indicate $95.9^{\circ} \pm 16.2^{\circ}$ counterclockwise rotation of the southern block with respect to the northern block. The difference in inclinations between those blocks is $11.4^{\circ} \pm 14.9^{\circ}$, which are not as significant as the amount of rotation. Characteristic paleomagnetic directions from syn-rift deposits of the Girón Fm in the two structural domains coincide with each other (Table 4), but stratigraphic thickness changes across inverted structures from a few hundred meters in the rotated southern block to $>4.5 \mathrm{~km}$ in the non-rotated northern block. Therefore, paleomagnetic data from the Jordán and Girón Fms indicate vertical-axis rotation of fault-bounded blocks associated to extensional deposition of the Girón Fm during the Late Jurassic (Fig. 8).

After converting the characteristic direction of the Macule river to southern directions, the mean inclination values between Chipalo and Macule river blocks become similar (the difference is $2.9^{\circ} \pm 28.9^{\circ}$ ), but declination values show evidence of vertical-axis rotations (Table 4, Fig. 4A). The comparison of declination values of characteristic components between the Chipalo and Macule blocks documents $43.3^{\circ} \pm 29^{\circ}$ counterclockwise vertical-axis rotation of Mac-

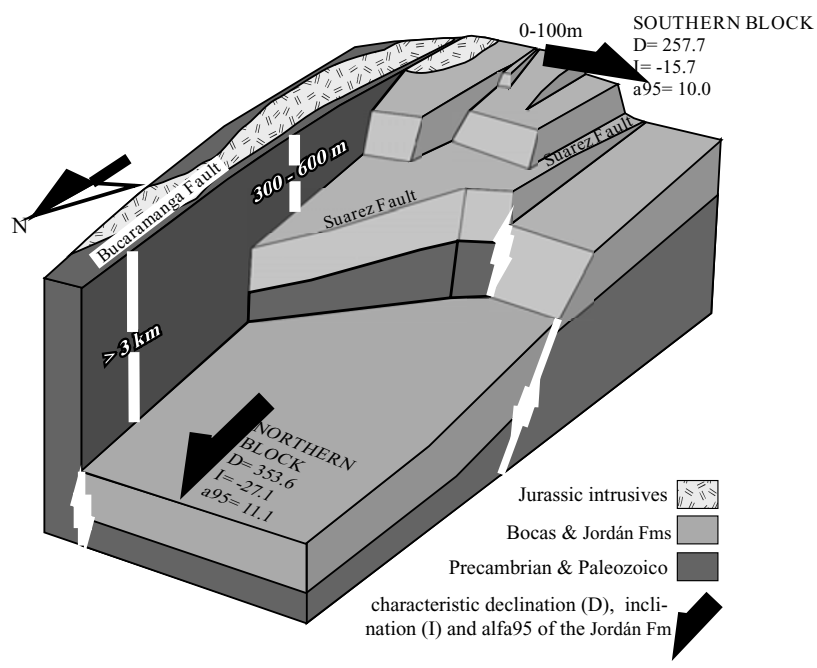

Fig. 8. Sketch showing the structural geometry of fault-bounded blocks after syn-extensional (transtensional?) deposition of the Girón Fm. Although strata of the Girón Fm are not shown for clarity, the range of stratigraphic thickness of this unit is shown for each structural block. The diagram shows the top of underlying units (Jordán and Bocas Fms). $95.9^{\circ} \pm 16.2^{\circ}$ counterclockwise vertical-axis rotation of the southern block may be associated to this extensional setting. The confidence limits for structural domain declinations and the difference of declinations follow the criteria given by Demarest (1983). ule block respect to Chipalo block. Even though the angle of alfa95 is very large, in part due to the low number of sites in the Macule river $(N=3)$, a change in stratigraphic thickness of the Yaví Fm from $0 \mathrm{~m}$ in the non-rotated Chipalo block to over $220 \mathrm{~m}$ in the rotated Macule block in less than $1.5 \mathrm{~km}$ additionally support this suggestion of faultbounded rotations.

Counterclockwise rotations reported in both $\mathrm{BA}$ and $\mathrm{OH}$ areas are associated to syn-extensional deposition and volcanism, suggesting a relationship among extensional tectonism, rotations of fault-bounded blocks and deposition. Paleomagnetic studies in transtensional systems of volcanic terranes document rotation of fault-bounded blocks (Dimitriadis et al., 1998; Wawrzyniec et al., 2001). Christie-Blick and Biddle (1985) indicate that vertical-axis rotations occur at diverse magnitudes and influence the process of generation of wrench-related sedimentary basins. Therefore, paleomagnetically determined vertical-axis rotations as inferred in this study indicate that block rotations associated to a transtensional system is a common mechanism that needs to be considered in the analysis of Mesozoic basins in the northwestern corner of the South America plate.

\section{Translation of Tectonic Terranes}

Comprehensive analysis of our results together with paleomagnetic data from Jurassic to Lower Cretaceous rocks exposed in the Santa Marta massif, Perijá Range, Mérida Andes and stable areas of South America shows northward translation of terranes west of the Bucaramanga and Borde Llanero Faults with respect to the craton and the above mentioned ranges (Table 2; Fig. 6). In the Early Jurassic, meanpaleolatitude values for terranes west of the Borde Llanero and Bucaramanga faults varies from $-14.4^{\circ}$ (BA) to $-3.6^{\circ}$ (UMV), but these values change significantly in the Late Jurassic-Early Cretaceous to $+7.5^{\circ}$ (FM) or $+11.3^{\circ}$ (BA) (see Table 4; Fig. 9B shows error bars for paleolatitudinal and age determinations). Northward translation of meanpaleolatitudinal values of a reference point in the craton $\left(4^{\circ} \mathrm{N}, 72^{\circ} \mathrm{W}\right.$, see position in Fig. 1A) from Early Jurassic to Early Cretaceous was only from $+0.9^{\circ}$ to $+6.2^{\circ}$ (Table 4 ; Fig. 9A shows error bars for paleolatitudinal and age determinations). Northern (positive) paleolatitudes have been determined for MA, PR, SMM, BA and FM since Middle to Late Jurassic, as well as for the stable craton. Therefore, our preliminary paleomagnetic data supports the hypothesis of along-plate margin accretion of those terranes west of the Borde Llanero fault system with respect to a reference point in the craton during the Early Jurassic and no change in paleolatitude since then (Fig. 9B). Even though Scott (1978) proposed translation of more than $20^{\circ}$ for the UMV terrane based on paleomagnetic analysis of Upper Triassic Luisa $\mathrm{Fm}$, it is necessary to re-evaluate those paleomagnetic data with a more detailed structural analysis of the sampled area.

Our conclusion is, however, heavily dependent on the accurate determination of the South American reference poles and the complex deformation history of terranes west of the Bucaramanga and Borde Llanero fault systems. The most generally accepted and more conservative reference poles as proposed by Randall (1998) or McElhinny and McFadden (2000) support a significant northward displacement 

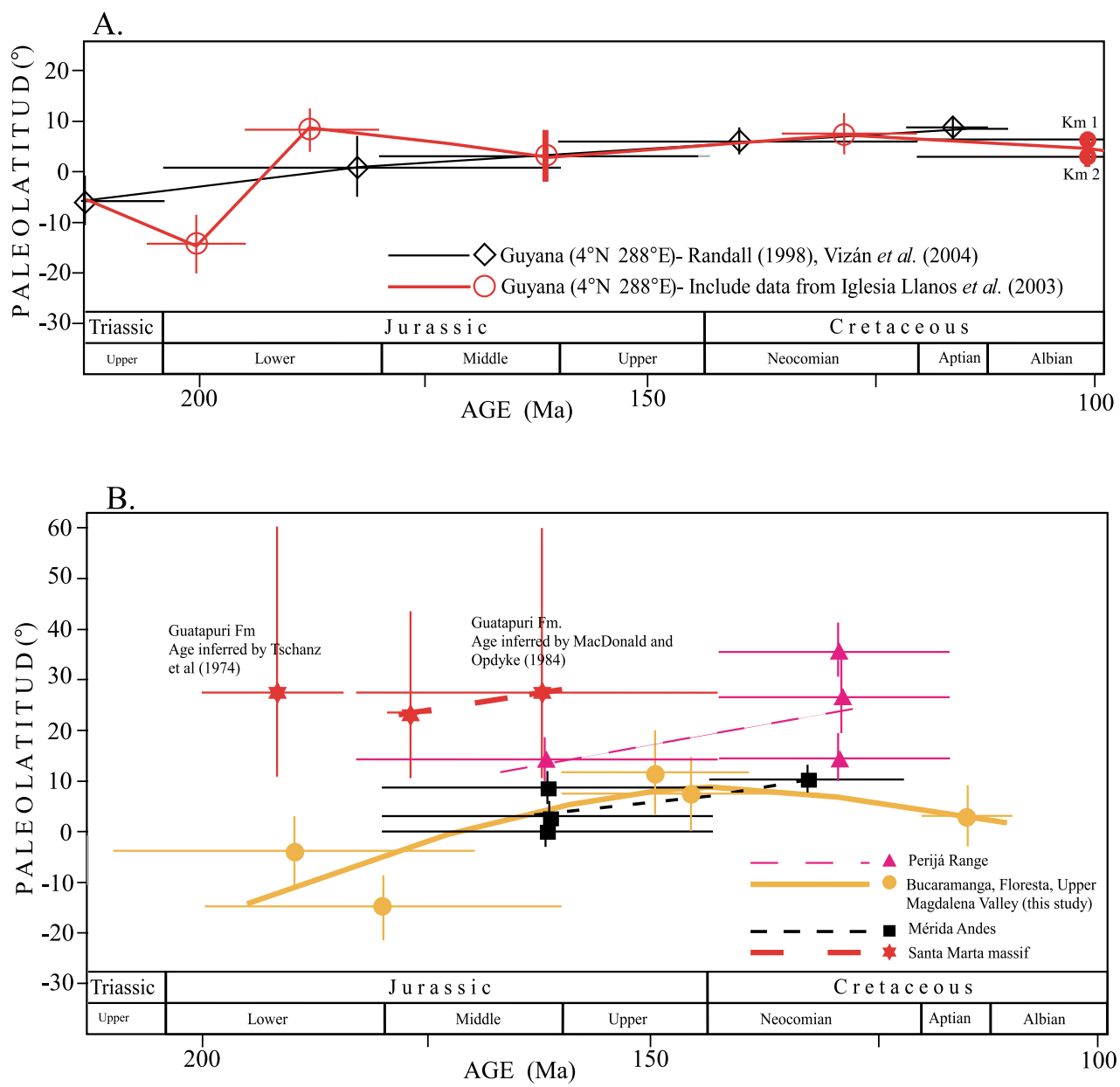

Fig. 9. Paleolatitude data for (A) the stable craton and (B) mountain ranges in the northern Andes with paleomagnetic data from Upper Triassic to Lower Cretaceous rocks. Note the contrasting difference in paleolatitudinal displacement of the craton in Early to Middle Jurassic time, in contrast to the uniform paleolatitude position of the craton since Late Jurassic. Similarly, accreted terranes show a northward displacement, but of a greater magnitude than the craton, during Early to Middle Jurassic time.

of terranes west of the Borde Llanero fault system. However an alternative selection of reference poles for the Early Jurassic (see for instance Iglesia Llanos et al., 2003) may significantly reduce the amount of northward displacement of these terranes. Until new reliable paleomagnetic data from tectonically stable areas of South America for the Triassic and Early Jurassic are obtained, we prefer the conservative reference poles that minimize the latitudinal displacement of South America in the Jurassic.

The early Mesozoic conceptual tectonic evolution presented here illustrates along-margin northward translation of terranes with respect a reference point in the craton (Fig. 10), as indicated by paleomagnetic data, and considers both geochemical and stratigraphic data of lower Mesozoic rocks. The model is based on the suggestion of northward displacement of accreted terranes in a greater magnitude than the northward displacement of a reference point in the South America craton. In addition, this model permits the proposition of two major tectonic events affecting the northwestern margin of South America. More detailed paleomagnetic work is needed in order to establish a more confident paleolatitudinal position for each accreted terranes.

The first tectonic scenario occurred during the Late Triassic and Early Jurassic and is related to an oblique sub- duction margin (Fig. 10B). A magmatic-arc belt formed as result of subduction along western Pangea, resulting in the southward continuation of the early Mesozoic continental magmatic arc developed from the southwestern United States to Guatemala (see figure 4 of Dickinson and Lawton, 2001). Marine (southward of SL) and continental (northward of SL) deposits were covered by thick volcaniclastic deposition in a continental arc-related (intra-arc, back-arc) setting. Calc-alkaline magmas intruded along a magmatic arc striking parallel to the subduction zone. This magmatic arc includes from north to south: SMM, SM, FM, SL and UMV.

In Middle-Late Jurassic to Early Cretaceous (Fig. 10C), northward translations of BA, FM and UMV terranes, westward retreat of the subduction zone and opening of the proto-Caribbean sea favored intracontinental extensional and/or transtensional deformation with development of basins filled by syn-extensional siliciclastic and volcaniclastic continental deposits in MA and PR, as well as in basins close to the Bucaramanga fault (near BA and FM). For Early Cretaceous, diachronous marine transgression inundated the latter basins and reached its maximum extension in mid to Late Cretaceous time (Etayo-Serna et al., 1976) (Fig. 10D). 
A. CONCEPTUAL TECTONIC MODEL

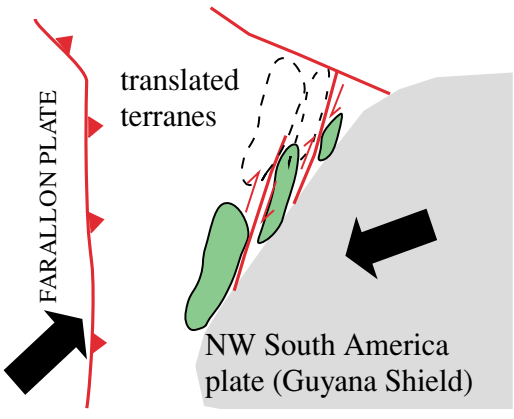

$\bigoplus$ reference point in the craton

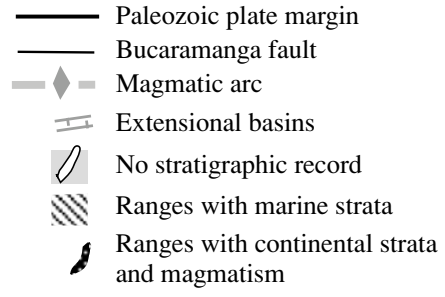

$\mathrm{F} / \mathrm{B}=$ Floresta massif, Bucaramanga area

MA = Mérida Andes

$\mathrm{PR}=$ Perija Range

$\mathrm{SL}=$ San Lucas range

$\mathrm{SM}=$ Santander massif

$\mathrm{SMM}=$ Santa Marta massif

$\mathrm{UMV}=$ Upper Magdalena Valley
B. LATE TRIASSIC-MIDDLE JURASSIC (160-220 Ma) Subduction-related magmatism

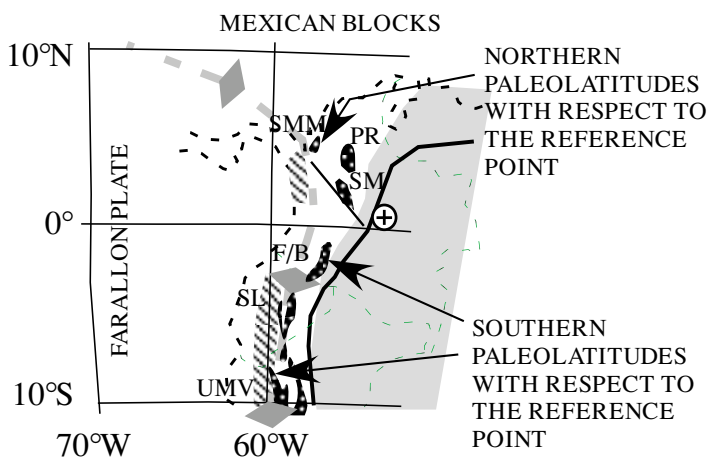

C. LATE JURASSIC-EARLY CRETACEOUS (121-160 Ma)

Syn-extensional (transtensional?) continental deposition

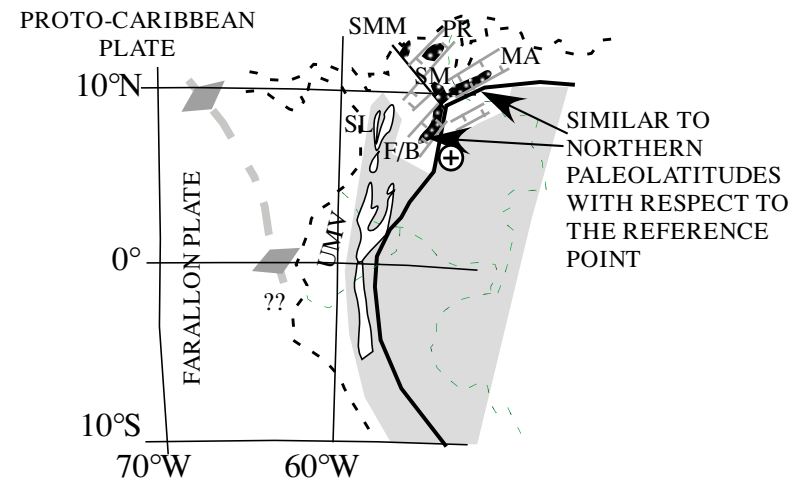

D. APTIAN-ALBIAN (100-120 Ma)

Marine and coastal deposition

PROTO-CARIBBEAN PLATE

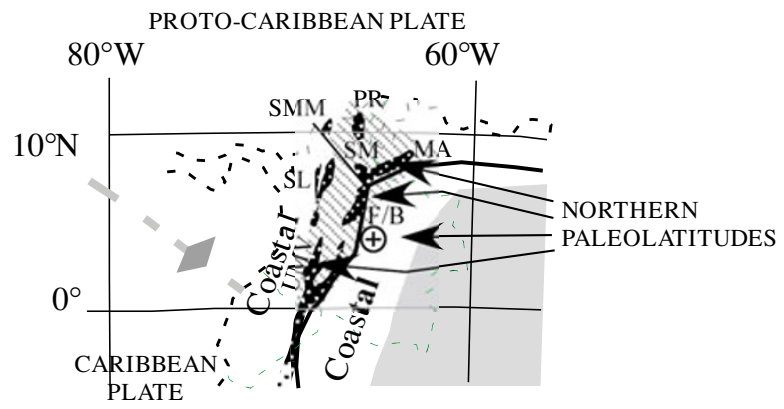

Fig. 10. (A) Conceptual tectonic model illustrating northward displacement of terranes in an oblique subduction margin. (B to D) Late TriassicAptian tectonic evolution of the northern Andes constrained by paleomagnetic and geochemical data, and distribution of plutonic/volcanic/ sedimentary/metamorphic rocks in major mountain belts. See Fig. 1A for present geographic distribution of Triassic and Jurassic rocks in northern South America. (A) calc-alkaline plutonic and volcanic rocks are aligned along a linear subduction-related magmatic arc. Upper Triassic-Lower Jurassic rocks in MA and PR have not been reported in the literature. Paleomagnetic data indicate along-margin translations of terranes west of the Borde Llanero fault system (FM, UMV) from south of the paleomagnetic equator; they had a greater northward latitudinal movement than MA and PR terranes, and a reference point in the South America craton. (B) Translations changed to a dominantly east-west direction, as suggested by Castillo et al. (1991). Extensional tectonism affected areas close to the Bucaramanga fault (FM, SM, PR, MA). (C) For Aptian time, the terrains are juxtaposed to the stable craton.

Structures formed by northward translations of terranes constituted weak zones where fault-bounded extensional/transtensional basins might have formed in Late Jurassic-Early Cretaceous time. Although the latter structures are presently buried by Andean structures, they acted as a major control during contractional deformation of the western (Cortés et al., in press) and eastern (Rowan and
Linares, 2000) thrust belts bounding the Eastern Cordillera.

New geochronological, isotopic and paleomagnetic investigations are necessary to fully test the proposed evolution of the region. A similar and coeval tectonic evolution from arc-related magmatism and continental deposition during middle Triassic to Middle Jurassic followed by slab rollback and post-arc rifting during Middle Jurassic to Early 
Cretaceous has been proposed for southwestern USA and Mexico (Dickinson and Lawton, 2001).

\section{Conclusions}

Low-temperature/coercivity magnetic components and moderate to high-temperature/coercivity characteristic magnetic components were successfully uncovered in Upper Triassic to Lower Cretaceous rocks exposed in the Upper Magdalena Valley, Floresta massif and Bucaramanga area (Fig. 1A). Characteristic paleomagnetic directions, isolated in dykes, lavas and tuffs in the Saldaña Fm, tuffs and red mudstones in the Yavi Fm, fine-grained siliciclastic rocks of the Girón Fm, lavas and red siltstones in the Jordan Fm, and in limestones in the Tibasosa Fm, are carried dominantly by hematite, Ti-magnetite, and magnetite. Even though individual field test are not statistically significant, the following arguments support the suggestion that characteristic components were recorded close to the time of deposition: (1) comparison of characteristic directions and magnetic mineralogy between units separated by unconformities, (2) cluster of characteristic directions increases during untilting of strata, (3) record of normal and reverse directions within the same stratigraphic unit; (4) high dispersion of characteristic directions isolated in conglomerate clasts, (5) comparison of characteristic directions of units of the same age but in different areas, and (6) comparison of reference cratonic paleopoles with VGP calculated for each characteristic directions. The comprehensive analysis of the results of this pioneer paleomagnetic study carried out in terranes between the Borde Llanero and Romeral fault systems and previous paleomagnetic data from the Andes of Venezuela and the south American craton permit the proposition of along-margin northward translations of those terranes with respect a reference point in the craton and counter-clockwise rotations between fault-bounded rocks in extensional settings. Our conceptual tectonic evolution of the northwestern margin of the South America plate permits the proposition of a linear, subduction-related, magmatic arc tectonic setting in the Late Triassic to Middle Jurassic followed by the onset of intracontinental extensional and/or transtensional deformation with development of basins since the Late Jurassic to the Early Cretaceous. More detailed paleomagnetic work is needed in order to establish a more confident paleolatitudinal position for each accreted terranes.

Acknowledgments. This research was funded by grants from the Instituto Colombiano para el Desarrollo de la Ciencia COLCIENCIAS (grant 7277-05-13616) and Fundación para la promoción de la Investigación y Tecnología del BANCO DE LA REPUBLICA (grant 1680). We acknowledge C. Ayala, G. Veloza, C. Silva, M. Casas, M. Aldana, M. Cortés and J. Roncancio for their help during the different phases of this project. Constructive comments and discussion with M. Cortés and R. Van der Voo helped to improve this manuscript. Revisions from Luis M. Alva-Valdivia and Wulf Gose contributed to a better presentation of the data and appropriate support of our interpretations.

\section{References}

Altenberger, U. and A. H. Concha-Perdomo, Late Lower to early Middle Jurassic arc magmatism in the northern Ibague-Batholith/Colombia, Geologia Colombiana, 30, 87-97, 2005.
Aspden, J. A., W. McCourt, and M. Brook, Geochemical control of subduction-related magmatism: the Mesozoic and Cenozoic plutonic history of Western Colombia, J. Geol. Soc. London, 144, 893-905, 1987.

Ayala-Calvo, R. C., G. Veloza, G. Bayona, M. Gomez-Casallas, A. E. Rapalini, V. Costanzo-Álvarez, and M. Aldana, Paleomagnetismo y mineralogía magnética en las unidades del Mesozoico de Bucaramanga y Macizo de Floresta, Geología Colombiana, 30, 49-66, 2005.

Bartolini, C., H. Lang, and T. Spell, Geochronology, Geochemistry and Tectonic setting of the Mesozoic Nazas arc in North-Central Mexico, and its continuations to Northern South America, in The Circum-Gulf of Mexico and the Caribbean: Hydrocarbon Habitats, Basin Formation and Plate Tectonics, edited by C. Bartolini, R. Buffler, and J. Blickwede, AAPG Memoir, 79, 427-461, 2003.

Bayona, G., D. Garcia, and G. Mora, La Formación Saldaña: producto de la actividad de estratovolcanes continentales en un dominio de retroarco, in Estudios Geológicos del Valle Superior del Magdalena, edited by F. Etayo-Serna, 21 pp., Universidad Nacional de Colombia, Chapter I, Bogotá, 1994.

Bayona, G., C. Silva, A. E. Rapalini, V. Costanzo-Álvarez, M. Aldana, and J. Roncancio, Paleomagnetismo y mineralogía magnética en rocas de la Fm. Saldaña y unidades Cretácicas suprayacentes en la parte norte del Valle Superior del Magdalena, Boletín de Geología, 27, 69-85, 2005.

Cajas, L., Estudio petrográfico de la Formación Saldaña entre los municipios de Alpujarra y Natagaima [Undergraduate thesis], Universidad Nacional de Colombia, Bogotá, 2003.

Castañeda, R., Caracterización petrográfica y geoquímica de la Formación Saldaña en un área del macizo Colombiano entre los departamentos de Cauca-Nariño y Putumayo [Undergraduate thesis], Universidad Nacional de Colombia, Bogotá, 2002.

Castillo, J., W. A. Gose, and A. Perarnau, Paleomagnetic results from Mesozoic strata in the Mérida Andes, Venezuela, J. Geophys. Res., 96, 6011-6022, 1991.

Cediel, F., R. Shaw, and C. Cáceres, Tectonic Assembly of the Northern Andean block, in The Circum-Gulf of Mexico and the Caribbean: Hydrocarbon Habitats, Basin Formation and Plate Tectonics, edited by C. Bartolini, R. Buffler, and J. Blickwede, AAPG Memoir, 79, 815-848, 2003.

Christie-Blick, N. and K. Biddle, Deformation and basin formation along strike-slip faults, in Strike-slip deformation, basin formation and sedimentation: Tulsa, Oklahoma, edited by K. Biddle and N. Christie-Blick, Society of Economic Paleontologist and Mineralogist Special Publication, 37, 1-34, 1985.

Cordani, U., A. Cardona, D. Jimenez, D. Liu, and A. Nutman, Geochronology of Proterozoic basement inliers from the Colombian Andes: Tectonic history of Remnants from a fragmented Grenville belt, in Terrane Processes at the Margins of Gondwana, edited by A. P. M. Vaughan, P. T. Leat, and R. J. Pankhurst, R. J., Geological Society, London, Special Publication, 246, 239-246, 2005.

Cortés, M., B. Colleta, and J. Angelier, Structure and Tectonics of the Central Segment of the Eastern Cordillera of Colombia, Journal of South American Earth Sciences, (in press).

Demarest, H. H., Jr., Error analysis for the determination of tectonic rotation from paleomagnetic data, J. Geophys. Res., 88, 4321-4328, 1983.

Dickinson, W. R. and T. F. Lawton, Carboniferous to Cretaceous assembly and fragmentation of Mexico, Geological Society of America Bulletin, 113, 1142-1160, 2001.

Dimitriadis, S., D. Kondopoulou, and A. Atzemoglou, Dextral rotations and tectonomagnetic evolution of the southern Rhopode and adjacent regions (Greece), Tectonophysics, 299, 159-173, 1998.

Dorr, W., J. R. Grosser, G. I. Rodriguez, and U. Kramm, Zircon U/Pb age of the Paramo Rico tonalite-granodiorite, Santander massif (Cordillera Oriental, Colombia) and its geotectonic significance, Journal of South American Earth Sciences, 8, 187-194, 1995.

Ernesto, M., G. Bellieni, E. Piccirillo, L. Marques, A. De Min, I. Pacca, G. Martins, and J. Macedo, Paleomagnetic, geochronological and geochemical constraints on time and duration of the Mesozoic igneous activity in Northeastern Brazil, In the Central Atlantic Magmatic province, Amer. Geophys. Union, Monograph Series, 136, 129-149, 2002.

Estrada, J., Paleomagnetism and accretion events in the northern Andes, Ph.D. Dissertation thesis, State University of New York, Binghamton, 1995.

Etayo-Serna, F., G. Renzoni, and D. Barrero, Contornos sucesivos del mar Cretácico en Colombia, Memorias Primer Congreso Colombiano de Geología, Bogotá, Colombia, 217-252, 1976.

Etayo-Serna, F., D. Barrero, H. Lozano, and other 15 authors, Mapa de 
Terrenos Geológicos de Colombia, 235 pp., Ingeominas, Bogotá, 1983. Fisher, R. A., Dispersion on a sphere, Proceedings of the Royal Society of London, Series A, 217, 295-305, 1953.

Forero, A., The basement of the Eastern Cordillera, Colombia: An allochthonous terrane in northwestern South America, Journal of South American Earth Sciences, 3, 141-151, 1990.

Gose, W. A., A. Perarnau, and J. Castillo, Paleomagnetic results from the Perijá Mountains, Venezuela: an example of vertical axis rotation, in The Circum-Gulf of Mexico and the Caribbean: Hydrocarbon Habitats, Basin Formation and Plate Tectonics, edited by C. Bartolini, R. Buffler, and J. Blickwede, AAPG Memoir, 79, 969-975, 2003.

Hargraves, R. B., R. Shagam, R. Vargas, and G. I. Rodriguez, Paleomagnetic results from rhyolites (early Cretaceous?) and andesite dikes at two localities in the Ocaña area, northern Santander massif, Colombia, in The Caribbean-South American Plate Boundary and Regional Tectonics, edited by W. E. Bonini, R. B. Hargraves, and R. Shagam, Geological Society of America Memoir, 162, 299-302, 1984.

Iglesia Llanos, M. P., R. Lanza, A. C. Riccardi, S. Geuna, M. A. Laurenzi, and R. Ruffini, Palaeomagnetic study of the El Quemado complex and Marifil Formation, Patagonian Jurassic igneous province, Argentina, Geophys. J. Int., 154, 599-617, 2003.

Jaillard, E. P., P. Solar, G. Carlier, and T. Mourier, Geodynamic evolution of the northern and central Andes during early to middle Mesozoic times: a Tethyan model, J. Geol. Soc. London, 147, 1009-1022, 1990.

Kerr, A. and J. Tarney, Tectonic evolution of the Caribbean and northwestern South America: The case for accretion of two Late Cretaceous oceanic plateaus, Geology, 33, 269-272, doi:10.1130/G21109.1, 2005.

Kirschvink, J., The least-squares line and plane and the analysis of palaeomagnetic data, Geophys. J. Roy. Astro. Soc., 62, 699-718, 1980.

Lowrie, W., Identification of ferromagnetic minerals in a rock by coercivity and unblocking temperature properties, Geophys. Res. Lett., 17, 159$162,1990$.

MacDonald, W. D. and N. D. Opdyke, Tectonic rotations suggested by paleomagnetic results from northern Colombia, South America, J. Geophys. Res., 77, 539-546, 1972

MacDonald, W. D. and N. D. Opdyke, Preliminary paleomagnetic results from Jurassic rocks of the Santa Marta massif, Colombia, in The Caribbean-South American Plate Boundary and Regional Tectonics, edited by W. E. Bonini, R. B. Hargraves, and R. Shagam, Geological Society of America Memoir, 162, 295-298, 1984.

Maze, W. B., Jurassic La Quinta Formation in the Sierra de Perijá, northwestern Venezuela; geology and tectonic environment of red beds and volcanic rocks, in The Caribbean-South American Plate Boundary and Regional Tectonics, edited by W. E. Bonini, R. B. Hargraves, and R. Shagam, Geological Society of America Memoir, 162, 263-282, 1984.

McElhinny, M. W., Statistical significance of the fold test in paleomagnetism, Geophys. J. Roy. Astro. Soc., 8, 338-340, 1964.

McElhinny, M. W. and P. L. McFadden, Paleomagnetism: Continents and Oceans, 386 pp., Academic Press, London, 2000.

McFadden, P. L. and M. W. McElhinny, Classification of the reversal test in Paleomagnetism, Geophys. J. Int., 103, 725-729, 1990.

McFadden, P. L. and A. B. Reid, Analysis of paleomagnetic inclination data, Geophys. J. Roy. Astro. Soc., 69, 307-319, 1982.

Mojica, J., A. Kammer, and G. Ujueta, El Jurásico del sector noroccidental de Suramérica y guía de la excursión al Valle Superior del Magdalena (Nov. 1-4/95), Regiones de Payandé y Prado, Departamento del Tolima, Colombia, Geología Colombiana, 21, 3-40, 1996.

Pindell, J. L. and K. D. Tabbutt, Mesozoic-Cenozoic Andean paleogeography and regional controls on hydrocarbon systems, in Petroleum basins of South America: Tulsa, edited by A. J. Tankard, R. Suarez, and H. J. Welsink, AAPG Memoir, 62, 101-128, 1995.

Randall, D., A new Jurassic-Recent apparent polar wander path for South America and a review of central Andean tectonic models, Tectonophysics, 299, 49-74, 1998.

Restrepo-Pace, P., Petrotectonic characterization of the central Andean terrane, Colombia, Journal of South American Earth Sciences, 5, 97 116, 1992.

Restrepo-Pace, P., Late Precambrian to Early Mesozoic Tectonic Evolution of the Colombian Andes, Based on New Geochronological, Geochemical and Isotopic Data, Ph.D. Dissertation thesis, Tucson, The University of Arizona, 1995.

Restrepo-Pace, P., J. Ruiz, G. Gehrels, and M. Cosca, Geochronology and $\mathrm{Nd}$ isotopic data of Grenville-age rocks in the Colombian andes: new constraints for Late Proterozoic-Early Paleozoic paleocontinental reconstructions of the Americas, Earth and Planetary Science Letters, 150, 427-441, 1997.

Rowan, M. and R. Linares, Fold-Evolution Matrices and Axial-Surface Analysis of Fault-Bend Folds: Application to the Medina Anticline, Eastern Cordillera, Colombia, American Association of Petroleum Geologists Bulletin, 84, 741-764, 2000.

Sarmiento-Rojas, L. F., Mesozoic Rifting and Cenozoic Basin Inversion History of the Eastern Cordillera, Colombian Andes; Inferences from tectonic models: Bogotá, ECOPETROL-Netherlands Research School of Sedimentary Geology, 295 pp., 2001.

Scott, G. R., Translation of accretionary slivers: Triassic results from the Central Cordillera of Colombia, EOS-Transactions Fall meeting supplements, 59(12), American Geophysical Union, 1058-1059, 1978.

Somoza, R., El campo magnético Cretácico desde una perspectiva americana, 15th Congreso Geológico Argentino, El Calafate, Argentina, Actas 1, 88-93, 2002.

Vasquez, M., G. Bayona, and R. L. Romer, Geochemistry of Jurassic volcanic Rocks of the Northern Andes: Insights for the Mesozoic Evolution of Northwestern Gondwana, 2006 Backbone of the Americas meeting, Geological Society of American and the Asociación Geológica Argentina, 2006

Vizán, H., R. Ixer, P. Turner, J. M. Cortés, and G. Cladera, Paleomagnetism of Upper Triassic rocks in the Los Colorados hill section, Mendoza province, Argentina, Journal of South American Earth Sciences, 18, 4159, 2004.

Ward, D., R. Goldsmith, J. Cruz, and H. Restrepo, Geología de los Cuadrángulos H-12, Bucaramanga y H-13, Pamplona, Departamento de Santander, Boletín Geológico Ingeominas, 21(1-3), 132 p., 1973.

Wawrzyniec, T., J. Geissman, E. Anderson, S. Harlan, and J. Faulds, Paleomagnetic data bearing on style deformation in the Lake Mead area, southern Nevada, Journal of Structural Geology, 23, 1255-1279, 2001.

Wilson, G. S. and A. P. Roberts, Diagenesis of magnetic mineral assemblages in multiply redeposited siliciclastic marine sediments, Wanganui Basin, New Zealand, in Paleomagnetism and Diagenesis in Sediments, edited by D. H. Tarling and P. Turner, Geological Society Special Publication, 51, 95-108, 1999.

Zijderveld, J. D. A., A. C. demagnetization of rocks: analysis of results, in Methods of Paleomagnetism, edited by D. W. Collison, K. M. Creer, and S. K. Runcorn, Elsevier Science, 254-286, 1967.

G. Bayona (e-mail: gbayona@cgares.org), A. Rapalini, and V. Constanzo-Alvarez 